\title{
En Büyük ve Mutlak Otorite: Kral-Tanrı Allah ve Krallığı.
}

\section{Halil HACIMÜFTÜOĞLU *}

The Greatest and Absolute Authority: King-God Allah and His Kingdom

Citation/@: Hacımüftüoğlu, Halil, (2017). The Greatest and Absolute Authority: King-God Allah and His Kingdom, Milel ve Nihal, 14 (1), 161-200.

Abstract: In this article, whether the concept of "God/The Realm of Gods", which also exists in other cultures, traditions and religions, also exists in Koran and authentic narratives, and if it does exist, whether it is used in its literal or figurative meaning has been studied through linguistic and historical evidence and "the nature of Allah's Realm" has been depicted with its main features and various aspects. The perception of the King-God is also found in Islam as much as it is in Judaism and Christianity. Throughout history 'God/Allah has always introduced itself as a 'king'. In the Qur'an and Islam, all concepts are directly or indirectly related to this perception. The perception of 'the kingdom of God' has been largely ignored for various.

Key Words: King, royal authority, the ninth heaven, throne, simile, figure (trope), metaphor, allegory.

· Bu makale Ankara Üniversitesi Sosyal Bilimler Enstitüsü Temel İslam Bilimleri, Tefsir Anabilim Dalı'nda Prof. Dr. Halis Albayrak danışmanlığında hazırlanan, doktora jürisi önünde 2009 yılında savunulan ve kabul edilen Kuran'da Allah'ın Krallığı adlı doktora tezimden üretilmiştir.

- Yard. Doç. Dr., Gaziantep Üniversitesi, İlahiyat Fakültesi, Tefsir Anabilim Dalı [halilmuftuoglu@gantep.edu.tr] 
Atıf/C: Hacımüftüoğlu, Halil, (2017). En Büyük ve Mutlak Otorite: Kral-Tanrı Allah ve Krallığı, Milel ve Nihal, 14 (1), 161-200.

Öz: Bu makalede diğer kültür, gelenek ve dinlerde bulunan 'Tanrı'nın Krallığı' algısının temel İslam kaynaklarında (Kuran ve sahih rivayetler) da mevcut olup olmadığı, mevcut ise 'Allah'ın Krallığı'nın gerçek veya mecaz manada algılanıp algılanmadığı dilsel, dinsel ve tarihsel delilleriyle ele alınmış, 'Allah'ın Krallığı'nın mahiyeti ana hatlarıyla ve kısmen değişik yönleriyle tasvir edilmeye çalışılmıştır. Kral-Tanrı algısı Yahudilikte ve Hıristiyanlıkta olduğu kadar İslam'da vardır. Tarih boyunca 'Tanrı/ Allah' kendisini her zaman bir 'kral' olarak tanıtmıştır. Kuran'da ve İslam'da tüm kavramlar doğrudan veya dolaylı olarak bu algı ile ilişkilidir. 'Allah'ın Krallığı' algısı son yüzyıllarda değişik nedenlerden dolayı büyük ölçüde gözden kaçırılmış, günümüze kadar da bunun farkına pek varılamamış ve gereği gibi araştırılmamıştır.

Anahtar Kelimeler: Melik/ melîk, mulk/ melekût, 'arş, teşbih, mecaz, istiare.

\section{Giriş}

Tarih boyunca değişik kültürlerde ve geleneklerde, ister semavi olsun ister olmasın neredeyse bütün dinlerde Tanrı veya tanrılar genellikle birer efendi/ sahip (İng. lord) ve kral olarak nitelendirilmiştir. Aslında 'Tanrı'yı nitelemek için bunlardan daha uygun sıfatlar ve unvanlar bulmak da imkânsızdı. Çünkü Tanrı, ancak gücün, kudretin, otoritenin, iktidarın, ihtişamın, asaletin ve mükemmeliyetin timsali olan bir efendi/ sahip ve kral olabilirdi. Öte yandan 'efendi/ sahip' veya 'kral' -ki bir kral aynı zamanda en büyük efendi/ sahip kabul edilir-1 ancak monarşilerde bulunur. 'Monarşi' ise, siyasi iktidarın tek bir kişinin iradesine bağlı olduğu bir yönetim biçimidir. Bu yönetim biçiminde, gerek insanları idare etme gerek devletin devamı ve düzeni için kanunlar koyma yetkisi

${ }^{1}$ Bostan ve Gülistan adlı iki klasik eserin sahibi Sadi (Şirazî) zamanının 'sultan'1 Ebubekir oğlu Sad'ı övmek ve uyarmak amacıyla şunları söylemektedir: "Böyle, Tanrı'nın hakkını eda eden bir kul, kullar için ne güzel bir 'efendi'dir." Sadi, Gülistan (çev.: Hikmet İlaydın), Ankara, Milli Eğitim Bakanlığ1 Yay., (1946), s.255. 
tek bir kişinin elindedir. Bu kişiye yönettiği toplumun tarihi, geleneği, inancı, soyu ve hüküm sürdüğü ülkenin genişliğine göre farklı dillerde 'kral, imparator, şah, padişah, han, hakan, hükümdar, emir ve bey'2 gibi değişik unvanlar verilmektedir. Bir monark (hükümdar), insanları yönetme hakkını bizzat kendinden alır; ona bu hakkı yönettiği insanlar bahşetmez. Monarşiler bilinen insanlık tarihinin hem en eski ve hem de en fazla uygulanan yönetim biçimidir. Monarşinin karşıtı sayılabilecek yönetim biçimi ise cumhuriyettir. Eski Yunan siteleri, kısmen Roma İmparatorluğu ve yakın çağlarda İtalya'da kurulan bazı şehir devletleri istisna edilirse son bir iki asra kadar devletler genellikle monark bir yöneticinin idaresi altında olmuştur. Öte yandan Allah Elçisi Muhammet'in ve dört ardılının (halîfe) hüküm sürdügü dönem de monarşik uygulamaların istisnalarından kabul edilir. Aristo'ya göre siyasal iktidarı tek başına elinde tutan monark, ailede babanın otoriter ve efendi olması gibi yönettiği bütün fertlerin de efendisidir. Onun yasalara uygun olarak çıkardığı emirlere ve kararlara mutlaka uyulmalıdır. Aksi takdirde devletin düzeni ve toplumun huzuru bozulur. ${ }^{3}$

\section{Farklı Kültürlerde Geleneklerde ve Dinlerde ‘Tanrı'nın/ Tan- rıların Krallığı' Algısı}

Babil Yaratılış Destanı (Enuma Eliş)'na göre, Babil'in ünlü tanrısı Marduk tanrılar panteonunun başı olan bir kraldı. Marduk başlangıçta sadece Babil şehrinin tanrısı iken sonraları bütün Babil'in en önemli tanrısı olarak kabul görmüştü. 'Babil'in Kralı', 'Yerin Göğün

\footnotetext{
2 Çeşitli kültürlerde büyük ölçüde dillerin farklı olması veya aynı kelimelerin farklı telaffuzları sebebiyle değişik gibi algılanan ama bazı nüanslar hariç hemen hemen aynı anlamda kullanılan bu vb. unvanları bu çalışmamızda aynı anlamda ve birbirinin yerine kullanacağız. Çünkü her biri öz olarak bir monarka (hükümdar; kral, imparator, sultan vs.) ve netice olarak aynı yönetim biçimine yani monarşiye (hükümdarlık, krallık, imparatorluk, saltanat vs.) işaret etmektedir. Dolayısıyla çalışmamızda mesela Kuran'daki ve rivayetlerdeki 'mulk/ melekût' kelimesini 'krallık (Allah'ın Krallığı)' yerine 'padişahlık, sultanlık, hükümdarlık..' olarak, 'melik/ melîk' kelimesini 'kral' yerine 'padișah, sultan, hükümdar' olarak da çevirmek mümkündür. Anılan kelimeleri bu şekilde çevirmemizin nedeni günümüzde 'krallık' ve 'kral' kelimelerinin diğer monarşik isimlendirmelere nazaran hem doğu ve hem de batı dünyasında artık kullanılıyor olmasıdır. Mesela batı dışında doğudaki bazı monarklara (Kral Hüseyin, Kral Abdullah, Kral Fahd...) da 'kral' denmektedir.

${ }^{3}$ Bk. "Monarşi" mad., (Komisyon), Sosyal Bilimler Ansiklopedisi, İstanbul, Risale Yay., (1990), c.III, s.49.
} 
ve Bütün Tanrıların Kralı' unvanlarını alan Marduk'un krallık tahtına oturma süreci Ortadoğu'daki siyasal çekişmelerle aynı özellikleri taşır. Zira o da birbirini bertaraf eden Ortadoğu kralları gibi diğer tanrılarla mücadele ederek ve savaşarak krallık tahtına oturmuştu. Suriye' nin kuzeyindeki antik Ugarit şehrinden çıkarılan ve M.Ö. 1400'lere tarihlenen Ras Shamra metinlerine göre tanrı Baal da bir kraldı. 'Bizim kralımız, yargıcımız' şeklinde tanımlanan Baal doğaya hükmeden güçlü bir kral tanrı olarak kabul edilmişti. $\mathrm{O}$ da tıpkı Marduk gibi bu konumunu mücadele ederek ve savaşarak elde etmişti. Onun krallığı elde edişini anlatan mitos her yıl kutlanan sonbahar yeni yıl festivalinde okunmaktaydı.

Eski İran kültüründeki Mecusiliğin yüce tanrısı olan AhuraMazda, hemen hemen bütün tarihi tasvirlerde kral kostümleri giymiş olarak, başında tacı ve iki yanında kartal kanatları ile betimlenmişti. O yüzden kabartmalarda Ahura-Mazda ile kral figürlerini birbirinden ayırt etmek oldukça zordur.

Sümerlerin iki ünlü tanrısı Enlil ve Enki'nin de birer kral olarak betimlendiğini görüyoruz. Enlil, 'Tüm Tanrıların Babası', 'Gökyüzünün ve Yeryüzünün Efendisi' ve 'Tüm Ülkelerin Kralı' gibi unvanlarla anılmıştı. Her şeyi yöneten Enlil'in kraliyet tahtı, 'Gökyüzünün ve Yeryüzünün Kemiği' diye nitelenen kutsal kent Nippur'daki tapınakta bulunuyordu. Bu tapınağa efendiler ile prensler duacılar getirtirler ve kurbanlar sunarlard1. Ayrıca bütün yabancı ülkeler oraya ağır vergiler öderdi. Enlil olmaksızın insan, hayvan veya bitki olsun hiçbir canlı üreyemezdi. Aynı zamanda o, insanlara karşı lütufkâr, onlara bolluk ve bereket getiren bir tanrrydı. Enki'ye gelince o da çok akıllı, herşeyi bilen, bilge ve önder bir tanrıydı; cömert bir velinimetti. Her şeyin adını bilen Enki, değiştirilemez ' $m e^{\prime}$ lerin yani evrensel yasaların ve kuralların idarecisi, dağıtıcısı, ülkelerin efendisi ve bütün ülkelerin babasıydı. Onun emirleri sorgulanmazdı. Enlil ve Enki'den başka göklerin tanrısı diye kabul edilen An da bir kral olarak nitelendirilmiş; onun bir kürsüde oturarak işleri idare ettiğine inanılmıştı.

Eski Mısır mitolojisinde baş tanrı olarak kabul edilen Horus, bir kral olarak algılandığı için Mısır kraliyet sembolü sayılan bir şahin ile tasvir edilmişti. Firavunların bile meşruiyetlerini ondan aldıklarına inanılırdı. Zira Mısırlılara göre tanrılar insanlara siyaseti öğreten ve örnek olan ideal krallardı. Görülmektedir ki, Ortadoğu 
tanr1-kral kültünde tanrılar, siyaseti ve idareciliği en iyi yapanlar olarak kabul edildiklerinden dolayı ideal krallar olarak sayılıyorlardı. Başlangıçta yeryüzünde krallık bizzat tanrılar tarafından yapılırken daha sonraları bu görev onların seçtikleri ve tayin ettikleri naiplere yani yarı insan yarı tanrı olduğu düşünülen varlıklara devredilmişti. ${ }^{4}$ Ancak yukarıda da zikredildiği gibi bazı kültürlerde ya gökteki tanrı bir kral addedilmiş ya da Roma ve Japon imparatorları örneğinde olduğu gibi yerdeki kral/ imparator 'tanrı'laştırılmıştır. ${ }^{5}$ Dolayısıyla her halükarda 'kral' ile 'tanrı' lık veya 'tanrı' ile 'kral'lık arasında bir tür ayrılmaz ilişki olduğu kabul edilmiştir. ${ }^{6}$

Yahudilik ve Hiristiyanlıkta da 'Tanrı' bir kral olarak kabul edilmiştir. Birçok Kitab-1 Mukaddes (Kutsal Kitap) ifadesi bunu açıkça ortaya koymaktadır. Bir kaç örnek verelim.

Rab [Doğrusu 'Efendi'] kutsal tapınağındadır, onun tahtı göklerdedir, Bütün insanları görür, Herkesi sınar.7

\footnotetext{
${ }^{4}$ Bk. Cengiz Batuk, Tarihin Sonunu Beklemek, İstanbul, İz Yay., (2003), ss.156-159.

${ }^{5}$ Eski Japonya imparatoru Hirohito, tanrısallık iddiasından Amerikan askeri kuvvetlerinin II. Dünya Savaşı'ndaki Japonya işgaline kadar feragat etmemişti. Öte yandan bu feragat, imparatorun bazı taraftarlarınca yok sayılmıştı [Bk. S.R.F. Price, Ritüel ve İktidar (çev.: Taylan Esin), Ankara, İmge Kitabevi Yay., (2004), s.59]. Bazı monarklar ta hayatta iken, bazıları ise ölümlerinden sonra tanrılaşt1rılmışlardır. Bu yüzden yaşamları boyunca tanrılaştırılmayan Hitit kralları için öldükleri zaman 'Tanrı oldu.' ifadesi kullanılırdı (Bk. Sibel Özbudun, Ayinden Törene, İstanbul, Anahtar Kitaplar Yay., (1997), s.101). Bir Roma imparatoru olan Vespasianus'un ölmek üzereyken 'Zannedersem bir tanrı oluyorum (Ut puta, Deus fio).' dediği aktarılır. Bk. Hilmi Yavuz vd., Dinler Tarihi Ansiklopedisi, İstanbul, Gelişim Yay., (t.siz), c.III, s.595.

${ }^{6}$ Krş. "Krallar Tanrıdır, Kahraman Değil”; “Nedir bir tanrı? Hükmetme (to krauton). / Nedir bir kral? Bir tanrı benzeri (isôtheos)." Price, age, s.76, 381.
}

7 Mezmurlar, (11.4). Bu dâhil bundan sonraki çeviriler bir komisyon tarafından hazırlanan Kitab-1 Mukaddes çevirisinden [Kutsal Kitap-Yeni Çeviri-, İstanbul, Kitab-1 Mukaddes Şirketi Yay., (2003)], 'ayet numaraları' kaynak metinde olduğu gibi metin içinde değil, dipnotta gösterilerek alıntılanmıştır. Alıntılanan çevirilerdeki 'rab' kelimesi de aslında 'efendi (Yun. kîrios; İbr. adonay)' anlamına gelmektedir. Öyle görünüyor ki, Kitab-1 Mukaddes çevirmenleri kelimenin bu anlamını açıkça vermek yerine görüldüğü şekilde tercüme(!) etmeyi anlamı çarpıtmak pahasına yeğlemişlerdir. Çünkü Türkçedeki 'rab' kelimesinin anlamı (tanrı) ile yukarıda verdiğimiz kaynak metindeki kelimelerin anlamı (efendi) aynı değildir. 'Efendi' unvanı hem insan ve hem de Tanrı için kullanılırken Türkçedeki 'rab' sözcüğü anlamından da çıkarılabileceği gibi sadece Tanrı için kullanılır. Çevirmenlerin bunun farkında olmaması mümkün değildir. Nitekim 
Ne müthiştir yüce Rab, Bütün dünyanın ulu Kralı... Çünkü Tanrı bütün dünyanın kralıdır. ${ }^{8}$

Rab egemenlik sürüyor, titresin halklar! Keruvlar arasında tahtına oturmuş, sarsılsın yeryüzü! ... Ey adaleti seven güçlü kral...9

Ey Tanrım, ey Kral, seni yücelteceğim, Adını sonsuza dek öveceğim... Sadık kulların sana övgüler sunar. Krallığının yüceliğini anlatır, kudretini konuşur; Herkes senin gücünü, krallığının yüce görkemini bilsin diye. Senin krallığın ebedi krallıktır, Egemenliğin kuşaklar boyunca sürer. ${ }^{10}$

Kutsalınız, İsrail'in Yaratıcısı, Kralınız Rab benim. ${ }^{11}$

Mübarek ve tek Hükümdar, kralların Kralı, rablerin Rabbi, ölümsüzlüğün tek sahibi, yaklaşılmaz 1şıkta yaşayan, hiç bir insanın görmediği ve göremeyeceği Tanrı, Mesih'i belirlenen zamanda ortaya çıkaracaktır. Onur ve kudret sonsuza dek O'nun olsun. Âmin. ${ }^{12}$

Burada akla şöyle bir soru gelebilir: 'Kitab-1 Mukaddes'teki 'Tanrı'nın Krallığı' kavramı gerçek anlamda mı, mecaz anlamda mı kullanılmıştır?' Meşhur Leviathan yazarı Hobbes bu konuda şunları söyler: “Tanrının Krallığgı', din adamları tarafından mecazî olarak alınır, fakat Kutsal Kitaplar'da gerçek anlamıyla. 'Tanrı'nın Krallı̆̆ ${ }^{\prime}$, din adamlarının yazılarında ve özellikle vaazlarda ve risalelerde, genellikle, bu hayattan sonra en yüksek cennetteki ebedi mutluluk olarak anlaşılır ve bu nedenle 'saadet diyarı' olarak da adlandırılır ve bazen de, 'lütuf âlemi' dedikleri, o en büyük mutluluk, takdis olarak anlaşılır; fakat asla monarşi, yani krallık kelimesinin

muhtemelen yine kendileri tarafından daha önce yapılmış İncil çevirisinin sadece 'Sözlük' kısmında bu anlam belirtilmiştir: "Rab 'efendi' ya da 'egemen' anlamına gelen Baba Tanrı'ya, İsa Mesih'e ve Kutsal Ruh'a verilen bir unvan." (Komisyon), İncil-Müjde, İstanbul, Yeni Yaşam Yay., (1991), s.559.

${ }^{8}$ Mezmurlar, $(47.2,7)$.

${ }^{9}$ Mezmurlar, $(99.1,4)$.

${ }^{10}$ Mezmurlar, (145.1, 10-13).

11 Yeşaya, (43.15).

${ }^{12}$ I. Timoteyus, (6.16). Bir Arapça Yuhanna İncili'nin başındaki ikona resminde İsa, 'Kralların Kralı (Meliku'l-Mulûk)', başka bir tabirle 'Hâkim-i Mutlak (Yun. Pantokrâtoras)' olarak resmedilmiştir. Bk. (Komisyon), el-İncîl li'l-kıddîsi Yuhannâ, Kahire, Dâru'l-Ma'ârif, (1997). 
asıl anlamı olan Tanrı'nın uyruklarının kendi rızasıyla onlar üzerinde sahip olduğu egemenlik olarak anlaşılmaz. Bense, aksine 'Tanrı'nın Krallığı' ifadesinin, Kutsal Kitap'ın pek çok yerinde, özel olarak İsrail kavminin oylarıyla kurulmuş 'tam anlamıyla bir krallık' anlamında kullanıldığını düşünüyorum; İsrail kavmi, Tanrı'nın onlara Kenan ülkesini verme vaadi üzerine, onunla yaptıkları ahitle Tanrı'yı kralları olarak seçmiştir ve bu ifadenin pek nadiren mecazî olarak kullanıldığ 1 kanısındayım ve mecaz olarak kullanıldığı zaman da 'günah üzerinde hâkimiyet' anlamında kullanılır; (ve sadece Yeni Ahit'te) çünkü 'Tanrı'nın Krallığı'nda her uyruk, egemene halel getirmeksizin, böyle bir hâkimiyete sahip olacaktır. Yaradılıştan beri, Tanrı gücüyle bütün insanlar üzerinde 'doğal olarak' hüküm sürmekle kalmamış; ayrıca, bir kimsenin başka birine konuşması gibi, bir sesle emir verdiği özel uyruklara da sahip olmuştur."13 Görünmez Kral Tanrı kitabının yazarı Wells de gelecekte kurulması için öngörülerde bulunduğu 'Tanrı Krallığı'ndan ne anlaşılması gerektiği ile ilgili benzer görüşler belirtir. Ona göre yeryüzündeki 'Tanrı Krallığı', bir metafor (istiare), bir ruhanî durum, bir rüya ya da belirsiz bir proje olarak görülmemelidir. $\mathrm{O}$, geçmişten günümüze süregelen insanlığın yakın ve kaçınılmaz yazgısıdır. ${ }^{14}$

Öte yandan sadece Yahudilik ve Hiristiyanlıkta değil, 'Cahillik Çağı (el-Câhiliyyeh)'nda var olan Haniflikte de ${ }^{15}$ Tanrı (Allah)'nın bir 'kral' olarak algılandığını 'hanif' şair Ebu's-Salt oğlu Ümeyye'nin şiirlerinden öğreniyoruz. Izutsu, Ümeyye'nin şiirlerinin ana temasını şöyle açıklamaktadır: "Bu dünyanın merkezinde yalnız bir tanrı vardır. Bu tanrı, var olan her şeyi idare eder. Onun, Allah dediği bu tanrı kavramının etrafında, O'nun mülkü ve saltanatı hakkında Kitab-ı Mukaddes'in düşüncesini görmekteyiz. Tanrı

${ }^{13}$ Thomas Hobbes, Leviathan (çev.: Semih Lim), İstanbul, Yapı Kredi Yay., (2008), s.286.

${ }^{14}$ Bk. H. G. Wells, Görünmez Kral Tanrı (çev.: Hatice Çoban), İstanbul, İzdüşüm Yay., (2000), s.102.

${ }^{15}$ Unutmayalım ki, Allah Elçisi Muhammet' in takipçileri kendilerini ataları İbrahim'in öğretisi olan (dînen giyemen millete İbrâhîme hanîfâ) 'el-Hanîfiyye' töre (dîn)sine mensup sayıyorlar; 'İslâm' sözcüğünü 'el-Hanîfiyye (Haniflik)' olarak açıklıyorlardı. Çünkü Allah elçisi, öğrettiği törenin Yahudilik veya Hıristiyanlık töresi değil, müsamahakâr 'el-Hanîfiyye' töresi (el-Hanîfiyyetu's-samhah) olduğunu ifade etmişti. Bu konuda bk. el-Bakara, 2/35; Âlu 'İmrân, 3/19, 95; en-Nisâ', 4/125; el-En'âm, 6/161; en-Nahl, 16/123; el-Buhârî, Bed'u'l-Îmân/ 29. 
göz kamaştırıcı bir nur perdesi içinde 'yalnız ve tek olarak' tahtında oturuyor. İnsan gözü, tanrıyı kuşatan bir nur perdesini geçip ulûhiyet varlığını göremez. Işık perdesi, mukaddes gök melekleriyle kuşatılmıştır. O bunlara 'desteklenmiş yaratıklar' diyor. Yani Allah'ın yardımıyla kuvvetlenmiş yaratıklar. Bunlar 'saf saf dizilmişler', kimi arşı [tahtı] taşıyor, kimi sessizce ilahî vahyi dinliyor. Bunlar arasında Cebrail, Mikail ve diğer bazıları en yüksek mevkii işgal ederler."16 Şair bazı şiirlerinde Allah'tan 'Hanifliğin efendisi... Ufukları saltanatıyla kaplayan (Rabbu'l-Hanîfeti... Tabbake'l-âfâke sultânâa)'17, 'bütün ulusların/ dünyanın tanrısı (ilâhu'l-'âlemîn)', 'göklerin ve yerin kralı (melîku's-semâvâti ve ardihâ)', 'kulların/ kölelerin efendisi (rabbu'l-'ibâd)' gibi nitelemelerle, insanlardan ise 'kullar/ köleler ('ibâd), halayıklar (imâ' ')' ve 'Allah'ın reayası (re'âye'llâh)' olarak söz eder. ${ }^{18}$

Gerek Kuran'a gerek sahih rivayetlere (ahâdîs) göre de Allah, bir 'efendi/ sahip (rabb)' olduğu kadar bir 'kral (melik)'dır aynı zamanda. ${ }^{19}$

'Şöyle söyle: 'İnsanların 'efendisine (rabbi'n-nâs), kralına (meliki'n-nâs)' ve tanrısına sığınırım (en-Nâs, 114/1-3).'

'O kusursuz olan, esenlik veren, emin kılan, koruyup gözeten, güçlü, şerefli ve gerektiğinde zor kullanmasını bilen gururlu' kral(el-melik)'dır (el-Haşr, 59/23).'

'Şöyle söyle: 'Ey krallı̆̆ın sahibi (mâlike'l-mulk) tanrım! (Âlu 'İmrân, 3/26)’

\footnotetext{
${ }^{16}$ Toshihiko Izutsu, Kur'ân'da Allah ve İnsan (çev.: Süleyman Ateş), Ankara, Kevser Yay., (t.siz), s.108.

${ }^{17}$ Allah Elçisi Muhammet'in yukarıdaki nitelemelerin bulunduğu şiiri terennüm ettiği ve 'Ümeyye'nin teslim (müslüman) olmasına ramak kalmıştı.' dediği rivayete edilir. Bk. el-Isbehânî, Ebu'l-Ferec, Kitâbu'l-Ĕ̆ĝân (tahk.: eş-Şeyh Ahmed eşŞankîtî), Matba'atu't-Tekaddum, Mısır, (t.siz), c.III, s.190.

${ }^{18}$ Bk. Izutsu, age, s.109, 110.

19 İlkel insanlara has bir korkuyla -Çünkü ilkel insanlar, başlarına bir bela geleceği endişesiyle, korktukları varlıkların adlarını telaffuz etmekten çekinirlerbazı kelimelerden ve onları telaffuz etmekten çekinmemek gerekir. Ayrıca bazı kelimeleri sembolleştirmenin, onlara duygusal yaklaşmanın veya onlar üzerinden niyet okumanın da bilimsel bir dayanağı yoktur. Bilimde istisnasız her şey, bir rahatsızlık veya endişe duymaksızın tartışılabilir; en emin olunan konular üzerinde bile yeniden düşünülebilir.
} 
'Gökler-Yer Krallı̆̆1 (mulku's-semâvâti ve'l-ard)' Allah'ındir (Âlu 'İmrân, 3/189).'

'O gün insanlar meydana çıkarlar. Hiçbir şeyleri Allah'a gizli kalmaz. O gün krallık (el-mulk) kimindir? Bir ve hükümran olan Allah'ındır (el-Mu'min, 40/16).'

'İşte kesin bilgi sahibi bir kimse olması için İbrahim'e 'Gökler-Yer Krallığı (melekûte's-semâvâti ve'l-ard)'nı böyle gösteriyorduk (el-En'âm, 6/75).'

'Ebuhureyre, Allah elçisinden şunları işittiğini rivayet eder:

'Yüce Allah yeri toplar ve sağ eliyle gökleri dürer. Sonra, 'Kral benim (Ene'l-melik)! Yeryüzünün kralları nerede (Eyne mulûku'l-ard)?' diye sorar.' ${ }^{20}$

'Ebuhureyre'nin rivayetine göre Allah elçisi şöyle demiştir:

'Yüce Allah'ın duruşma günü (yevme'l-kıyâmeh) ${ }^{21}$ en fazla öfkeleneceği kimse unvanı 'krallıkların kralı' olan kimselerdir. Zira Yüce Allah'tan başka kral (melik) yoktur.'22

'Ebu'd-Derda rivayet eder:

'Allah habercisi (neb̂̂) şöyle demişlerdi: 'Size, hangi eyleminizin kralınız nezdinde ('inde melîkikum) daha hayırlı, daha uygun... olduğunu haber vereyim mi? ...'23

Şunu da belirtmek gerekir: Kitab-1 Mukaddes'te geçen 'Tanrı'nın Krallığı' algılamasına Allah ve elçisi tarafından hiçbir itirazda bulunulmamıştır. Hatta kaynaklarda 'Şöyle veya böyle anlaşılmalıydı.' türünden bir itiraza dahi rastlanmamaktadır. İtiraz bir

${ }^{20}$ el-Buhârî, et-Tefsîr-ez-Zumer/ 2; ed-Dârimî, er-Rikâk/ 80.

${ }^{21} \mathrm{Bu}$ şekilde çevirmemizin asıl nedeni el-Mutaffifûn suresinde bu büyük günden 'Yevme yekûmu'n-nâsu li rabbi'l-'âlemîn (el-Mutaffifûn, 83/6)' yani 'Ínsanların, ulusların efendisi için ayağa kalktığı gün' diye bahsedilmesidir. Zira insanlar o gün hâkim (yargıç) olan Allah'ın divanında birer sanık gibi ayakta durarak yargilanacaklardır.

22 el-Buhârî, el-Edeb/ 114. Ayrica bk. Ebû Bekr Ahmedu'bnu'l-Huseyni'bni 'Alî el-Beyhakî, el-Esmâ' ve's-Sıfât (tahk.: eş-Şeyh 'İmâdu'd-dîn Ahmed Haydar), Beyrut, Dâru'l-Kitâbi'l-'Arabî, (2002), c.I, s.65.

${ }^{23}$ et-Tirmizî, ed-Da'avât/ 6. Ayrıca bk. İbnu Mâceh, el-Edeb/ 53. Şair Sabi oğlu Hassan ile şaire Hansa'nın Allah'tan 'kralımız (melîkinâ)' diye bahseden dizeleri için bk. Abdu'r-Rahmân Berkûkî, Şerhu Dîvâni Hassâne'bni Sâbitini'l-Ensârî, Misır, el-Mektebetu't-Ticâriyyetu'l-Kubrâ, (1929), s.13; Luis Şeyhû, Enîsu'l-Culesấ fi Şerhi Dîvâni'l-Hansâ', Beyrut, (1896), s.48. 
yana Allah Elçisi Muhammet'in Allah'ın 'kral'lığından söz eden Yahudi bir hahamı tasdik ettiğine dair sahih rivayetlere bile tesadüf etmek mümkündür. Bir rivayet şöyledir:

'Mesut oğlu Abdullah'ın şöyle dediği rivayet edilir:

'Yahudi bilginlerden biri Allah elçisine gelerek: 'Muhammet! Biz, Allah'ın gökleri bir parmağına, yerleri bir parmağına, ağaçları bir parmağına, su ve toprağı bir parmağına ve nihayet diğer yaratıkları da başka bir parmağına koyduktan sonra 'Ben kralım.' diyeceğini okuruz.' dedi. Allah elçisi, Yahudi bilginin söylediğini tasdik anlamında ön dişleri görünürcesine güldü. Sonra şunu okudu: ‘Onlar Allah'ı gereği gibi tanıyamadılar. Bütün yeryüzü duruşma günü onun avucundadır. Gökler onun sağ eliyle dürülmüş olacaktır... (ez-Zumer, 39/67)’24

\section{III. 'Allah'ın Krallı̆̆ı' Gerçek Bir Krallık Mıdır?}

Günümüzde bizde birkaç akademik çalışmadaki küçük atıflar hariç tutulursa 'Allah'ın Krallığı'ndan ${ }^{25}$ neredeyse hiç söz edilmez, daha doğrusu akademisyenlerimiz de dâhil çoğu kimse bundan haberdar bile değildir. ${ }^{26}$ Söz edilmemesinin ve dolayısıyla genellikle halkımızın haberdar olmamasının nedenleri olarak aşağıdaki hususları zikredilebiliriz.

${ }^{24}$ el-Buhârî, et-Tefsîr-ez-Zumer/ 2. “Bir gün [Yahudi asıllı bilgin] Ka'bü'l-Ahbâr: 'Veylun li meliki'l-ardi min meliki's-semâ" = Arz melikinin semâ meliki elinden hâli yamandır.' demiş. Hazret-i Fârûk-1 A'zam derhal: 'illâ men hâsebe nefseh.'= Meğerki nefsi ile hesaplaşmış ola.' kaydını ilave buyurmuş. Ka'bü'l-Ahbâr: 'Nefsimi yed-i kudretinde tutan Allah'a kasem ederim ki, Tevrat'ta da böyledir. Sen ona tâbi' olmuş oldun.' demiş ve Hazret-i Ömer hemen secde-i şükrâna kapanmış." Zeynü'd-dîn Ahmed b. Ahmed b. Abdi'l-Latîf ez-Zebîdî, Sahîh-i Buhârî Muhtasarı Tecrîd-i Sarîh Tercemesi ve Şerhi (terc. ve şerh: Ahmed Naim; Kâmil Miras), Ankara, Diyanet İşleri Başkanlığı Yay., (1982), c.II, ss.348-353, dipnot:1.

25 'Allah'ın Krallığı' ifadesiyle hem Allah'ın 'kral' oluşunu ve hem de bir 'krallık'ın bulunuşunu kast ediyoruz.

${ }^{26}$ Bk. Ömer Özsoy, "Dinsel Bir Metin Olarak Kur'an'ın Bazı İfade Özellikleri”, I. Kur'an Sempozyumu, Ankara, Bilgi Vakfı Yay., (1994), s.183; Muhammed Hamidullah, İslâm Peygamberi (çev.: Mehmet Yazgan), İstanbul, Beyan Yay., (2004), s.123. Bildiğimiz kadarıyla akademik eserlerin dışında buna en çok atıf yapan Bediuzzaman Said Nursi'nin eserleridir. Bediuzzaman, risalelerinde Allah'tan, 'sultan-1 mutlak, sultan-1 ezeli, sultan-1 sermedi[ebedi], âlemin... padişahı, sultan-1 kâinat', krallığından ise 'saltanat-1 ilahiye; sultan-1 ezelin saltanatı' vb. tamlamalarla bahseder. Bk. Bediuzzaman Said Nursi, Sözler, İstanbul, Envar 
Bizde Kuran'da ve sahih rivayetlerde geçen 'Allah'ın Krallığ1' ile ilgili kelimeler, kavramlar veya ifadeler genel olarak tercüme edilmeden yani çeviribilim terimiyle ifade edecek olursak ödünçlenerek sözde Türkçeye çevrilmektedir. Kanaatimize göre bunun bir davadaki delilleri karartmaktan hiçbir bir farkı yoktur. Evet, kelimeler lâfzen zihnimizde ve dilimizde var ama neredeyse hiçbiri hakiki manasını ifade edememektedir. Bir nevi bulunduğumuz mekânda onlarca lambalardan oluşan muhteşem bir avizemiz var ama karanlık olduğunda ne yazık ki birileri tarafından elektrikler kesildiği için üzerindeki lambalar bizleri aydınlatamamaktadır. Mesela Kuran'daki rabb, melik/ melîk ${ }^{27}$, mulk/ melekût ve' arş' kelimelerini ele alalım. Bu kelimeler çoğu kez tercüme edilmeden, ödünçleme yapılarak 'rab, melik, mülk, melekût' ve 'arş' olarak sözüm ona Türkçeye aktarılmaktadır.

Diğer taraftan ilgili kelimeler, kavramlar veya ifadeler tercüme edilse bile genellikle doğru düzgün tercüme edilmemektedir. Mesela yine yukarıda zikredilen kelimelerini ele alalım: "Kuran'daki ' $r a b b$ ' sıfatının (unvanının) asıl anlamı, bazı kaynaklarda ifade edilen meşhur anlamın aksine 'eğitici/ terbiyeci (murabbî)'28 değil, 'sahip (mâlik)'tir. Buna bağlı olarak ikinci anlamı ise 'efendi (İng. lord)'dir. ${ }^{29}$ Böyle olduğunun en bariz delili her iki kelimenin üçer

Neşriyat, (1995), s. 10, 52, 85, 287, 458; Bediuzzaman Said Nursi, Muhakemat, İstanbul, Envar Neşriyat, (1995), s. 13.

${ }^{27}$ 'Semî" ve "alîm' kelimeleri gibi olan 'melîk' kelimesi, 'melik' kelimesinden daha mübalağalıdır. el-'Askerî, Ebû Hilâl, el-Furûku'l-Luğaviyyeh (tahk.: Îhâb Muhammed İsmâ'îl), Mektebetu İbn'i Sînâ, Kahire, 2013, s. 134.

${ }^{28}$ Bk. er-Râğı el-Isfehânî, Mufredâtu Elfâzi'l-Kur'ân (nşr. Safvân Adnân Dâvûdî), Dimeşk, Dâru'1-Kalem, (1992), s. 336; Hüseyin Atay; İbrahim Atay, Arapça-Türkçe Büyük Lügat (Mu'cemu'l-Luğa), Ankara, (1964), s. 661; Serdar Mutçalı, ArapçaTürkçe Sözlük, İstanbul, Dağarcık Yay., (1995), s. 303; Mevdudi, Kur'an'a Göre Dört Terim (çev.: İsmail Kaya; Osman Cilacı), İstanbul, Beyan Yay., (t.siz), ss. 35-39; Ahmet Çelik, Kur'an Semantiği Üzerine, Erzurum, Kültür Eğitim Vakfı Yay., (2002), ss. 34-37.

${ }^{29}$ Bk. Ebü'l-Kasım Cârullâh Muhammed b. Ömer ez-Zemahşerî,, el-Keşşâf, Beyrut, Dâru'l-Kütübi'l-'İlmiyye, (2009), c. I, s. 20; İsmâ'îlu'bnu Hammâd el-Cevherî,, Mu'cemu's-Sihâh (i'tinâ': Halîl Me'mûn Şeyhâ), Beyrut, Dâru'l-Ma'rifeh, (2008), 208, s. 283; Arthur Jeffery, The Foreign Vocabulary of The Qur'ân, Baroda, Oriental Instute, (1938), s. 136; Muhammed Esed, Kur'an Mesajı Meal-Tefsir (çev.: Ahmet Ertürk; Cahit Koytak), İstanbul, İşaret Yay., (1996), c. I, s.2, dipnot: 2. 
tane olan kök harflerinin $\left(r \hat{a}^{\prime}-b \hat{a}^{\prime}-b \hat{a}^{\prime} \text { ve } r \hat{a}^{\prime}-b \hat{a}^{\prime}-v \hat{a} v\right)^{30}$ ilk ikisi aynı olsa bile son kök harflerinin ( $b \hat{a}^{\prime}$ ve $v \hat{a} v$ ) farklı oluşu ve bunların birbirine dönüşmesi (kalb) gibi bir durumun Arapçada mümkün olmamas1dır. Ayrıca ' $r a b b$ ' kelimesinin zıt anlamlısı ' abd (kul; köle)' kelimesidir. ${ }^{31}$ Zira 'kulun/kölenin efendisi' ve 'sahibi' (Likulli 'abdin rabb) olur. Netice olarak ' $r a b b$ ' ve 'murabbî' kelimelerinin hem kelime kökü ve hem de anlam bakımından bir alakası esasen bulunmamaktadır. Kuran'daki 'terbiye (rabbâ - yurabbî) kelimesinin asıl anlamı, 'eğitmek (terbiye etmek)' değil, 'beslemek/ besleyip büyütmek'tir. ${ }^{32}$ Firavunun, Musa'yı 'Ve fa'alte fa'leteke'lletî fa'alte ve ente mine'l-kâfirîn (eş-Şu'arâ', 26/19).' yani 'Sonunda yapacağını yaptın işte. Sen nankörün tekisin!' diyerek 'nankörlük'le nitelemesinin nedeni, onu Nil nehri kenarında bir sandık içinde sahipsiz bir bebek olarak bulup 'besleyip büyütmesi'ne rağmen (kendi açısından) nankörlük etmesi idi. Nitekim onun Musa'ya 'E lem nurabbike fînâ velîden ve lebiste finnâ min 'umurike sinîn (eş-Şu'arâ', 26/18).' yani 'Biz seni yanımızda besleyip büyütmedik mi; nice yıllar sen aramızda yaşamadın mı?’ şeklindeki sitem dolu sözleri de bunu ispat etmektedir. Eski Arapçada 'eğitmek (terbiye etmek)' anlamındaki kelime ise Allah Elçisi Muhammet'e atfedilen 'Eddebenî rabbî fe ahsene te'dîb̂̂ (Beni efendimeğitti ve güzel de eğitti)'33 sözlerinde geçen 'te'dîb (eddebe-yu'eddibu)' ${ }^{\prime 34}$

Türkçede 'rab' kelimesi sadece 'tanrı' anlamına gelmekte ve Arapçadaki asli anlamını (sahip, efendi) asla yansıtmamaktadır [Bk. İsmail Parlatır vd., Türkçe Sözlük, Ankara, Türk Dil Kurumu Yay., (1998), c.II, s.1837]. Arapçadaki 'rabb' kelimesinin 'sahip, efendi' anlamlarına gelmesi başka, tanrı (Allah) için kullanılması başka şeydir.

${ }^{30} \mathrm{Rabb}$ kelimesinin kök (sülasi) mastar1 '(rabbe-yerubbu) rabben', rubai mezid ism-

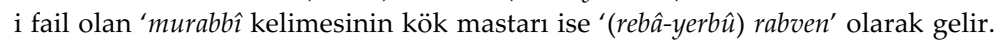
Bk. ez-Zemahşeri, age, c.I, s.20; el-Cevherî, age, s. 382, 383.

${ }^{31}$ Mevdudi, age, s. 38.

32 Bk. Zeynu'd-Dîn Ebû 'Abdi'llâh er-Râzî,, Tefsîru Ğarîbi'l-Kur'âni'l-'Azîm (tahk.: Hüseyin Elmalı), Ankara, Türkiye Diyanet Vakfı Yay., (1997), s. 553; el-Cevherî, age, s. 382 .

${ }^{33}$ Celaleddîn Abdurrahmân es-Suyûtî, el-Câmi'u's-Să̆̂̂r, Beyrut, Dâru'1-Kütübi'1'İlmiyye, (2004), no:310, c.I, s. 25.

${ }^{34}$ Arapçada 'edeb (eğitim)' ile 'ilmu'l-edeb/ edebiyyât (edebiyat)' arasındaki sıkı ilişkinin muhtemel nedeni Allah elçisinin doğduğu toplumda da adet olduğu üzere eski devirlerde çocuklara verilen başlıca eğitimin 'hitabet' eğitimi olmasıdır (Krş. "mueddib: terbiye eden, eğitimci; mueddeb: terbiyeli." Mutçalı, a.g.e, s. 10) Mesela eski Roma'da avukatların aldığı tek eğitim hitabet eğitimi idi. 
kelimesidir." 35 Öte yandan rabb kelimesi eski Arapçada krallar için de kullanılan bir sifat ve unvandır.

Çünkü bir kral genellikle kölelerin sahibi ve efendisi olmasından da öte hukuken bütün krallığın sahibidir ve efendisidir. Dolayısıyla da en büyük sahip ve efendi ancak bir kral olmaktadır. Yusuf suresinde Allah habercisi Yusuf'un kralın elçisine, 'Írci' ilâ rabbik (Yusuf, 12/50)' yani 'Efendine geri dön.' derken kastettiği 'efendi $(r a b b)^{\prime}$ devrinin mevcut Misır kralıydı. Nitekim Yusuf suresindeki mezkûr ayet ile diğer bir kısım ayetlerde ve bazı eski Arap şiirlerinde geçen ' $r a b b$ ' kelimesi kaynaklarda 'melik (kral)' olarak tefsir ve tercüme edilmiştir. ${ }^{36}$

Kuran'daki 'melik/ melîk' kelimesine gelince, bu kelime de Türkçe Kuran ve hadis tercümeleri ile diğer dini kaynaklarda Allah dışında insanlar için genellikle 'kral, padişah, hükümdar, sultan' şeklinde doğru tercüme edilmesine rağmen birkaç istisna hariç olmak üzere ${ }^{37}$ Allah için genellikle 'hükümran; mülkün sahibi, varlık üzerinde mutlak hakim, egemen..' vb. ${ }^{38}$ şekillerde kısmen veya tamamen yanlış tercüme edilmiştir. Buna paralel olarak 'mulk/ melekût' kelimesi de beşer krallıklar için doğru olarak 'krallık, saltanat' olarak doğru tercüme edilmesine karşın Allah için genellikle ‘hükümranlık, egemenlik'39 şeklinde tercüme edilmiştir. 'Arş̧ kelimesi

${ }^{35}$ Halil Hacımüftüoğlu, "Kuran'da ve Hadislerde 'Rabb' Sıfatının ve 'Rukû"' ile 'Secde' Fiillerinin Tahsisi', Bilimname, 2013/ 1, c.XXIV, s.105, 106.

${ }^{36}$ Bk. Yusuf, 12/41, 42, 43, 50, 51, 54); er-Râzî, age, s.104; Ebû 'Abdi'llâh el-Huseyn ez-Zevzenî, Şerhu'l-Mu'allakati's-Seb', Beyrut, Dâru'1-Ma'rifeh, (2004), s.245; [Ebû 'Abdi'llâh el-Huseyn ez-Zevzenî], Yedi Askı (çev.: Kenan Demirayak; Nevzat H. Yanık; Nurettin Ceviz), Ankara, Ankara Okulu Yay., (2004), s.109, 113; Çelik, age, s.61; el-Cevherî, age, s.383.

${ }^{37}$ Mesela el-Haşir suresinde geçen 'el-melik (el-Haşir, 59/23)' kelimesinin 'padişah' ve 'hükümdar' şeklinde çevirisi için bk. Süleyman Ateş, Kur'an'ı-Kerim ve Yüce Meali, İstanbul, Yeni Ufuklar Neşriyat, (t.siz), s.547; Talat Koçyiğit, Kur'an-ı Kerim Meali, Konya, Nükte Yay., (2005), s.285.

${ }^{38}$ Bk. Salih Akdemir, Son Çă̆rı Kur'an, Ankara, Ankara Okulu Yay., (2004), s.547; Hüseyin Atay, Kur'an Türkçe Çeviri, Ankara, Atay ve Atay, (2002), s.547; Edip Yüksel, Mesaj Kuran Çevirisi, İstanbul, Ozan Yay., (2003), s.480.

${ }^{39}$ Mesela bk. Koçyiğit, age, s.35; Akdemir, age, s.74; Atay, age, s.74; Yüksel, age, s.78. 
de hakeza insanlara ait olduğunda 'taht', Allah'a ait olduğunda 'yönetim/ hükümranlık' ve 'arş' olarak aktarılmıştır. ${ }^{40}$ Hâlbuki aynı kelimeler insanlar için de Allah için de aynı manada kullanılmışlardır. Buna dair diğer argümanları daha detaylı olarak aşağıda izah etmeye çalışacağı.

Kuran'da ve sahih rivayetlerde geçen 'Allah'ın Krallığı' ile ilgili kelimeler ve ifadeler doğru tercüme edilseler dahi genellikle son yüzyılda ilahiyatla ilgili ilgisiz birçok akademisyen ve entelektüel tarafından birer mecaz (metafor; istiare) ${ }^{41}$ veya sembol ${ }^{42}$ olarak yorumlanmaya ve izah edilmeye çalışılmaktadır. Hâlbuki bu kelimelerin hiçbiri Kuran'da ve sahih rivayetlerde Allah için mecaz veya sembol olarak kullanılmamıştır. Buna dair temel argümanları tek tek izah etmeden önce şunu belirtelim ki 'Allah'ın Krallığg' ile ilgili Kuran'da ve sahih rivayetlerde zikredilen kelimeler, kavramlar, ifadeler ve hususlar yukarıda zikredilenlerden ibaret değildir. Yani Kuran'da ve sahih rivayetlerde Allah'in sadece kral ve efendi olduğu, tahtı ve bir krallığı bulunduğu söylenerek yetinilmez. Kral olarak onun değişik vasıflarından, hasletlerinden, krallığının müesseselerinden vs. de bahsedilir. Mesela onun kendi özel adına (Allâh) ek olarak diğer 'mükemmel/ güzel sanları (unvanları), namları ve sıfatları (el-esmâu'l-husnâ)'43 bulunmaktadır. Çünkü özellikle büyük

\footnotetext{
${ }^{40}$ Mesela aynı isim ve sıfatlardan oluşan ve aynı bağlamda geçen en-Neml suresi 22. ayetteki Sebe kraliçesinin 'büyük taht ('arşun azîm)'1 ile 26. ayetteki Allah'ın 'büyük taht (el-arşi'l-'azîm)'1 farklı tercüme edilmiştir. Bk. Yüksel, age, s.329; Suad Yıldırım, Kur'ân-ı Hakîm'in Açıklamalı Meali, İstanbul, Işık Yay., (2005), s.378. Her iki ayette geçen "arş' kelimesini 'taht' olarak çeviren meal yazarı da bulunmaktadır. Bk. Şaban Piriş, Kur'an-ı Kerim Türkçe Anlamı, İstanbul, Okyanus Yay., (2004), s.178.

${ }^{41}$ Muhammed Arkoun, Kur'an Okumaları (çev.: A. Zeki Ünal), İstanbul, İnsan Yay., (1995), s.93, 94; Nevzat Tarhan, Akıldan Kalbe Yolculuk: Bediüzzaman Modeli, İstanbul, Nesil Yay., (2012), s.186. Ramazan Yazçiçek, “Metafizik Alanda Sörf ya da Mecaz ve Semboller Üzerinden Anlamlandırma: Bir Anlatım Yöntemi Olarak Metafor", Milel ve Nihal, (2012), c.IX, sayı:1, s.139.

42 Bk. Ömer Faruk Yavuz, Kur'an'da Sembolik Dil, Ankara, Ankara Okulu Yay., (2006), s.279, 286; Muhammed Hamidullah, "İslam'da Sembolik Anlatım ( çev.: Sadık Kılıç)”, Ankara, Diyanet Dergisi, (1989), c.XXV, sayı:1, s.4, 14.

${ }^{43}$ Kuran'daki 'el-ism (çoğ. el-esmâ')' kelimesi, 'isim, özel isim' yanında 'sıfat, nam, şan, unvan' gibi anlamlara da gelmektedir. Bu anlamlar, kelimenin geçtiği bir kaç Kuran pasajından da rahatlıkla çıkarılabilir. Bk. el-Bakara, 2/31; Âlu 'İmrân, 3/45; en-Necm, 53/.23; el-A`lâ, 87/1).
} 
krallar ve yöneticiler sadece özel adlarıyla anılmazlar. Onlar kendi özel adları dışında zamanla edindikleri bazı sanlarla, meşhur oldukları birtakım namlarla ${ }^{44}$ veya sıfatlarla ${ }^{45}$ da anılırlar. ${ }^{46}$

'Gökler-Yer Krallığı'nın sahibi, efendisi ve kralı olan Allah'ın sözü, işareti, iması, emirdir (vahy); yazısı/ mektubu ferman (kitâb)dır. ${ }^{47}$ Çünkü "mutlak bir kralın sözü, yazısı (Far. fermân: emir; buyruk) işareti, işmarı ve bir iması bile sadık kulları tarafından emir ve kanun olarak telakki edilmektedir. Sadik kullar, bir konuda harekete geçmek için efendilerinden sadece bir işaret beklerler. Bazı şeyleri anlamak için arif kullara (el-mutevessimîn $)^{48}$ bir işaret bile yeter. Hatta bazı eski kültürlerde genellikle bir kral olarak betimlenen Tanrı'nın hiç konuşmadığı; bir işin yapılması için sadece bir işarette bulunmasının kâfi geldiği düşünülürdü. ${ }^{49}$ Mesela, "Grekler için Tanrı, daha çok Grek dilinde konuşur, ya da söyler; Tanrı insana işaret eder. Burada Heraklitos'un meşhur fragmanını hatırlayalım: Delphoi'de kehanet yapan üstat, hiçbir şey konuşmaz ve hiçbir şey gizlemez; fakat işaret eder (Oute legei oute cryptei alla semainei)."50 Onun iradesini söze dökmesine gerek yoktur. Bunu benzer bazı zincirleme telakkiler takip etmektedir: Onun kararı 'buyruk'tur; 'iş (emr)'tir; 'oluş'tur ve 'yaratma' dır. ${ }^{51} \mathrm{O}$, bir şeyi emir buyurdu mu, o

${ }^{44}$ Bulunan eski tabletlerde Babil' in meşhur kralı Hammurabi' den 'Ülkenin Atası' ve 'Çoban' gibi namlarla bahsedilmiştir. Bk. Horst Klengel, Kral Hammurabi ve Babil Günlü̆ğ̈̈ (çev.: Nesrin Oral), İstanbul, Telos Yay., (2001), s.122, 123.

${ }^{45}$ Mesela Osmanlı padişahları için birçok sıfat içinde özellikle 'Allah'ın yeryüzündeki gölgesi (Zıllu'llâhi fi'l-ard)' sıfatı çokça kullanılmıştır. Bk. Fahri Unan, İdeal Cemiyet İdeal Devlet İdeal Hükümdar, Ankara, Lotus Yay., (2004), s.319.

${ }^{46}$ Krş. "Tanrı'nın İsimleri” mad., Yusuf Besalel, Yahudilik Ansiklopedisi, İstanbul, Gözlem Gazetecilik Basın ve Yayın A.Ş. Yay., (2002), c.III, s.718.

${ }^{47}$ Biz, Kuran'da Allah'a nispet edilerek kullanılan 'kitâb (çoğ. kutub)' sözcüğünü 'ferman/ buyruk' olarak çeviriyoruz. Bu şekilde çevirimiz ve Kuran algımız için bk. Halil Hacımüftüoğlu, Kuran Tercümelerinde Yöntem Sorunu, İstanbul, İz Yay., (2008), s.139, 140. Krş. el-Bakara, 2/2; en-Nisâ', 4/103; en-Neml, 27/28).

${ }^{48}$ el-Hicr, 15/75.

${ }^{49}$ Bizde büyük biriyle konuşurken 'Efendim, zat-1 âlinizin... dediği gibi.' yerine nezaketen 'Efendim, zat-1 âlinizin... işaret ettiği/ buyurduğu/ işaret buyurduğu gibi.' söylenmesi bundandır.

${ }^{50}$ Zeki Özcan, Teolojik Hermenötik, İstanbul, Alfa Basım Yayım Dağıtım, (1998), s.12.

51 “İbranicede dabar, kesinlikle hem 'söz' anlamına, fakat hem de 'eylem' anlamına gelir... Dabar'ın karmaşıklığı bize, Tanrı'nın sözünün, eyleminin muadili 
şey olmuş bilinmelidir. Kuran'da büyük küçük her şeye 'âyet (işaret)'... denmesi de bu yüzdendir. Ayrıca biliyoruz ki krallar tebaalarının kılavuzları ve önderleri sayılırlar. Bir kılavuz yol gösterir. Kralların tablolarda veya heykellerde ekseriyetle tebaalarının önünde işaret parmağıyla bir yöne işaret ediyor tarzda betimlenmesinin sebebi onların rehberliklerini ve liderliklerini vurgulamaktır." ${ }^{52}$ Allah da kendine tabi olanların kılavuzu ve lideridir (hudâ).

Her krallığın bir tek efendisi/ kralı olur. ${ }^{53}$ Bir krallıkta birden fazla efendinin/ kralın varlığı kargaşa çıkartır. Odysseus, İlyada'da topluluğa şöyle seslenir: "Her kafadan bir ses çıkarsa iyi olmaz; bir tek baş olmalı, bir tek kral." ${ }^{54}$ Mengü Han'ın, zamanın Fransa kralına yazdığı mektupta şu cümleler yazılıdır: “Ebedi Tanrı'nın emri şudur: Gökte sadece bir Tanrı var ve yeryüzünde de sadece bir efendi; Tanrı'nın oğlu Cengiz Han olacaktır." ${ }^{55}$ Allah da krallığında bir ve tektir. Affetmeyeceği en büyük hata, iktidarına birilerini veya bir şeyleri ortak etmektir. Çünkü mutlak iktidar şirk (ortaklık) kabul etmez ve krallar veya başka unvanlı hükümdarlar bu konuda çok kıskanç ve hassastırlar. Halife Me'mun'un şöyle dediği nakledilir: “Biz hükümdarlar zümresinde müthiş bir 'haset [kıskançlık]', sahiplenme ve zorbalık eğilimi vardır." 56 Aynen onun ifade ettiği gibi Kitab-ı Mukaddes'teki kral Tanrı da kıskanç bir tanrıdır. Kuran'da ise Allah'ın 'kıskanç' olduğu açıkça belirtilmez. Ancak bazı sahih rivayetlere bakılırsa Allah da kıskanç bir tanrıdır.

olduğunu gösterir; o güçtür ve eylemde bulunur; onun sözü etkinlikte bulunmayı başaramaz değildir. Söz mükemmelen (par excelence) ilahî faaliyettir (wor$k i n g)$... Bu söz, yalnızca yaratıcı güç değildir; aynı zamanda buyurma gücüdür de. O bir Tanrı kararı[hükmü]'dır. O, her şeyden önce bir karar, sonra da tarihe yerleşen bir karardır." Jacques Ellul, Sözün Düşüşü (çev.: Hüsamettin Arslan), İstanbul, Paradigma Yay., (2004), ss.80-82. Ayrıca bk. J. Walter Ong, Sözlü ve Yazılı Kültür (çev.: Sema Postacioğlu Banon), İstanbul, Metis Yay., (2003), s.47, 93.

52 Hacımüftüoğlu, Halil, Kuran Tercümelerinde Yöntem Sorunu, s.127, 128.

53 "Zira demişler ki: 'On derviş bir seccade üzerinde uyur da iki padişah bir iklime sığmaz." Sadi, age, s.29.

${ }^{54}$ Homeros, İlyada (çev.: Azra Erhat; A. Kadir), İstanbul, Can Yay., (1993), s.95.

${ }_{55}$ Günay Tümer; Abdurrahman Küçük, Dinler Tarihi, Ankara, Ocak Yay., (1993), s.79.

${ }^{56}$ Ebû Mansur es-Seâlibî, Hükümdarlık Sanatı (çev.: Sait Aykut), İstanbul, İnsan Yay., (1997), s.52. 
Başka ilahlara tapmayacaksınız. Çünkü ben adı Kıskanç bir Rabb'im, kıskanç bir Tanrı'yım. ${ }^{57}$

‘Ebuhureyre anlatır:

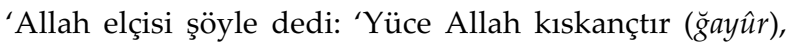
kendisine bağlanan kimse de. Yüce Allah'ın kıskandığ şey, kendisine bağlı bir kulun yasaklanmış bir şeyi yapmasıdır.'58

Krallar övünmeyi, övülmeyi ve gururlanmayı severler. Mesela Sümer kralları ilahilerinde daima ülkelerine ve halklarına sağladıkları zenginlik ve refahtan dolayı kendileri ile övünürler. ${ }^{59}$ Kramer bunun sebebini şöyle açıklar: "Kral ilahilerinin çoğu kendi kendine aşırı bir övgü niteliğindedir; kralların kendileri, yine kendileri hakkında hiçbir çekinme ve sınırlama gereği hissetmeksizin tumturaklı, abartılı ve kibirli övgü ezgileri söyler gibi yansıtılmaktadır. Kralların bu olağandışı ve bizim görüşümüzce pek değersiz olan davranışı, psikolojik bakımdan hiç de önemsiz değildir; genel olarak Sümer davranış tarzının karakteristik özelliği olan saygınlık ve üstünlük dürtüsüne uygun düşmektedir."60

Osmanlı padişahlarının özellikle zamanın ya da geçmişin gayrimüslim krallarına ve imparatorlarına karşı kendileri ile övündüklerini biliyoruz. Mesela Fatih Sultan Mehmet'in, "Sezar ve Anibal bile benimle karşılaştırılınca hiçbir şeydir ve ben (dünyadaki bütün Hıristiyanları) hâkimiyetim altına alabilirim." 61 diyerek kendisi ile

\footnotetext{
${ }^{57}$ Misır'dan Çıkış, (34.14).

${ }^{58}$ el-Buhârî, en-Nikâh/ 107; et-Tirmizî, er-Radâ'/ 14. “Kadı İyaz, kıskançlık manasına olan [Arapça rivayet metninde geçen] 'ğayret' in, kelime olarak 'teğayyürü'l-kalb'ten inşikak ettiğini söyler. Şöyle der: 'Bu kendine mahsus olan şeyde müşâreke (ortaklık) sebebiyle öfkenin kabarması, kalbin tegayyürüdür.' Bu hal, en ziyade karı-koca arasında olur. Söylediğimiz bu husus insanlar hakkındaki kıskançlı̆̆ı açıklar." İbrahim Canan, Kütüb-i Sitte Muhtasarı Tercüme ve Şerhi, Ankara, Akçağ Yay., (1990), c.XII, s.287.

${ }^{59}$ Bk. Samuel Noah Kramer, Sümerler (çev.: Özcan Buze), İstanbul, Kabalcı Yay., (2002), s.347. Kral Hammurabi'nin, yasalarında olduğu gibi bütün resmi yazılarında da kendisini kusursuz ve yanılmaz olarak tanıtmaya çalıştığı görülür. Bottéro, Hammurabi yasalarının temel özelliğinin kralın kendisi ile övünmesi olduğunu söyler. Bk. Jean Bottéro, Mezopotamya (çev.: Ayten Er; Mehmet Emin Özcan), Ankara, Dost Kitabevi Yay., (2003), s.207.

${ }^{60}$ Kramer, Sümerler, s.274.

${ }^{61}$ Unan, age, s.11, dipnot:20.
} 
övündügü nakledilir. Torunu Kanuni Sultan Süleyman'ın, zamanın Fransa kralına gönderdiği meşhur ferman ise kendisi ile ne kadar övündügünün veya başka bir deyişle Fransa kralına ne kadar tepeden baktığının açık bir belgesidir. ${ }^{62}$ Esasen kusursuz olmayan yeryüzünün beşer hükümdarları kendileri ile övünürken ve gururlanırken hepsinin ve her şeyin sahibi, Gökler-Yer Krallığı'nın sahibi, efendisi, kralı, evrende gerçekten, tamamen ve yegâne mü-

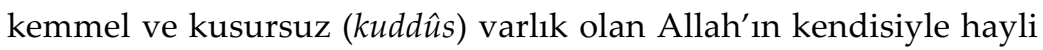
hayli övünmesi ve gururlanması (mutekebbir) gerekir. Çünkü övünmek ve gururlanmak ona yakışır. Hatta onun dişında hiç kimsenin bir kul olarak bunlara hakkı yoktur ve zaten her bakımdan kusursuz ve mükemmel olmadığı için kendi ile övünmek ve gururlanmak bir kula yakışmaz da.

'O kusursuz olan, esenlik veren, emin k1lan, koruyup gözeten, güçlü, şerefli ve gerektiğinde zor kullanmasını bilen ${ }^{63}$ gururlu kraldır (el-Haşr, 59/23).'

'Şunu söyle: 'Çocuk edinmeyen ve krallığında herhangi bir ortağ1 olmayan Allah bütün övünceleri (el-hamd) haizdir (el-İsrâ', 17/.111).'

‘Mesut oğlu Abdullah anlatır:

62 “Ben ki sultânü's selâtîn ve burhânü'l havakîn tâc bahş-i hüsrevân-1 rûy-i zemîn zıllu'llâhı fi'l-arzeyn Akdeniz'in ve Karadeniz'in ve Rumeli'nin ve Anadolu'nun ve Karaman'ın ve Rum'un ve Vilâyet-i Zülkadriye'nin ve Diyarbekir'in ve Kürdistan'ın ve Azerbeycan'ın ve Acem'in ve Şam'ın ve Halep'in ve Mısır'ın ve Mekke'nin ve Medine'nin ve Kudüs'ün ve külliyen diyâr-1 Arab'in ve Yemen'in ve dahâ nice memleketin ki âbâ'-i kirâm ve ecdâd-1 'izâmım Cenâb-1 Celâlet meâbım dahî tığ-1 ateşbâr ve şemşîr-i zafer-i nigârım ile fetheylediğim nice diyârın sultânı ve padişâhı, Sultân Bayezid Han Oğlu Sultân Selim Han Oğlu Sultân Süleyman Han'ım. Sen ki Françe vilâyetinin Kralı Françeşko'sun..." André Clot, Muhteşem Süleyman (çev.: Turhan Ilgaz), İstanbul, Milliyet Yay., (1998), s.143.

63 'Gerektiğinde zor (güç) kullanmasını bilen' diye çevirdiğimiz 'el-cebbâr' veya aynı kökten gelen ' $\mathrm{el}$-cebr' sıfatları ayn zamanda 'kral' ve 'sultan' anlamına gelmektedir. "İzâ beleğe'l-fitâme lenâ sabiyyun tehirru lehu'l-cebâbiru sâcidinna -'Emzikli bebelerimiz, sütten kesildiklerinde, krallar (el-cebâbir)_önlerinde yere kapanırlar [ez-Zevzeni, age, s.195. Ayrıca bk. Çelik, age, s.60]." 'Sultan, insanları dilediği şeye zorladığı ya da onların işlerini düzelttiği için 'cebr' olarak nitelendirilmiştir.' el-Isfehânî, age, s.183. 
'Allah elçisi şöyle demiştir: '... Methedilmekten Allah kadar hoşlanan hiç kimse de yoktur. Bu sebeple o kendisini methetmiştir.' ${ }^{64}$

'Ebuhureyre anlatir:

'Allah elçisi şöyle demiştir: ‘Güçlü, şerefli ve haşmetli Allah dedi ki: 'Büyüklük ve azamet benim üstlük ve altlık iki elbisemdir. Bu konularda benimle rekabete kalkışanı ateşe atarım.' 65

Krallar, mükemmel ve kusursuz oldukları düşünüldükleri için de ilke olarak yaptıklarından dolayı kolay kolay sorgulanmazlar. Öte yandan krallıklar, kralların mülkü kabul edilmiştir. Nasıl ki her mülk sahibi mülkü üzerinde istediği gibi tasarrufta bulunabiliyorsa her kral da krallığında istediği gibi tasarrufta bulunabilir. Nitekim ikinci 'meşrutiyet' ilan edildikten sonra hazırlanan 1909 tarihli Osmanlı Devlet Anayasası'nın beşinci maddesinde bile padişahın kimseye karşı sorumlu olmadığı, "Zât-1 hazret-i padişahînin nefs-i hümâyûnu mukaddes ve gayr-i mes'uldür." ${ }^{66}$ ifadesiyle açıkça beyan edilmişti. Söz konusu zat Allah yani ‘Gökler-Yer Krallığı'nın sahibi, efendisi ve kralı olduğuna göre hiç kimsenin onu sorgulamaya hakkı yoktur. Çünkü o, mükemmeldir; kusursuzdur. Bu mevzuda Kitab-1 Mukaddes'te ve Kuran'da şu ifadelere rastlarız:

Ama ey insan, sen kimsin ki Tanrı'ya karşılık veriyorsun? Kendisine biçim verilen, biçim verene, 'Beni niçin böyle yaptın?' der mi? Ya da çömlekçinin aynı kil yığınından bir kabı onurlu iş için, ötekini bayağı iş için yapmaya hakk1 yok mudur? ${ }^{67}$

'O, yaptıklarından dolayı sorgulanmaz (Lâ yus'el) ama onlar sorgulanırlar (el-Enbiyâ', 21/23).'

'Onun verdiği hükmü sorgulayacak kimse ( $\left.L \hat{a} m u^{\prime} a k k \imath b\right)$ yoktur (er-Ra'd, 13/41).

${ }^{64}$ et-Tirmizî, ed-Da'avât/ 97; el-Buhârî, en-Nikâh/ 107.

${ }^{65}$ Ebû Dâvûd, el-Libâs/ 28; Muslim, el-Birru ve's-Sılatu ve'1-Âdâb/ 38.

${ }^{66}$ (Komisyon), Kânûn-i Esâsî, Meclîs-i Meb’ûsân Riyâset Başkitâbetî, İstanbul, (h. 1330), s.12.

${ }^{67}$ Romalilar, $(9.20,21)$. 
Tarih boyunca daima 'kral'lık ile 'bilge' lik arasında bir tür ilişki olduğu veya en azından olması gerektiği düşünülmüştür. ${ }^{68}$ Çünkü bir kral aynı zamanda bilge bir şahsiyet olmalıdır ki tebaasına bir baba gibi yol göstersin; onlara adilane hükmetsin ve memleketini ileri bir düzeye taşısın. ${ }^{69} \mathrm{Ya}$ da tersinden söylemek gerekirse ancak bilge biri kral olmalıdır. ${ }^{70}$

Gerek Kitab-1 Mukaddes'te gerek Kuran'da kendisinden söz edilen Allah'ın habercisi Davut oğlu Süleyman da bir 'bilge kral'dı. Yahudilik Ansiklopedisi Kitab-1 Mukaddes'teki 'Süleyman'ın Özdeyişleri' veya eski çevirisiyle 'Meseller (İbr. Mişle)' kitabı hakkında şu bilgileri verir: “Bu kitap, Vaiz (Koelet) ve İyov kitabı ile birlikte günlük yaşamda ahlaki davranışlar sergilenebilmesi için akıllıca söylenmiş deyişleri içeren ‘Bilge Edebiyatı'na dâhildir... Rabinik geleneğe göre, kitaptaki bazı deyişler Agur ve Kral Lemuel gibi kişilere mal edilmişse de, bunlar Kral Şelomo [Süleyman]'yu tarif eder... Meseller kitabı çeşitli üsluplar içerir. Fakat bunların başlıca türleri deyişler ve talimatlardır." ${ }^{\prime 1}$ Eski sözlü kültürlerde bilge kralların birer

68 “İyi öğütler kimden gelirse gelsin hükümdarın bilgeliğinin ürünüdürler ve bu bilgelik ise, hiç de iyi öğütlerin ürünü değildir." Nicolo Machiavelli, Hükümdar (çev.: Selahattin Bağdatlı), İstanbul, Der Yay., (1999), s.135.

${ }^{69}$ Bilindiği gibi Kastilya kraliçesi Donia Isabelle ile evlenen İspanya kralı Aragon'lu Don Ferdinand, İberik Yarımadası'ndan Yahudilerin ayrılmasına neden olan bir ferman neşretmişti. Diğer taraftan Yahudilerin el sanatları, ticaret ve tıp alanındaki maharetlerinin farkında olan Osmanlı sultanı II. Bayezid onları ülkesine kabul etmişti. Bunun sonucunda belli bir süre sonra Osmanlı ülkesinde el sanatları, ticaret ve tıp gelişti; İspanya'da ise geriledi. Ferdinand'ın böylesine kötü sonuçlar veren bir ferman neşretmesi karşısında II. Bayezid'in şöyle dediği rivayet edilir: 'Ferdinand'in bilge (hakîm) ve akıllı bir kral olduğunu nasıl söylersiniz? Adam kendi ülkesini daha fakir benimkini ise daha zengin yapt.' Will Durant, Kıssatu'l-Hadârah [The Story of Civilation] (çev.:?), www.alsakher.com (28.06.2010), c.IX, s.8944,

${ }^{70}$ Platon'a ve Farabi'ye göre ancak bir filozof (bilgeliksever) hükümdar olabilir (Bk. Unan, age, s.110). Yakın bir zamanda vefat etmiş eski Bosna Hersek Cumhuriyeti cumhurbaşkanı Alija İzzetbegoviç, bir kral olmamasına rağmen halkı tarafından 'Bilge Kral' namıla anılmaktadır.

${ }^{71}$ Besalel, age, c.II, s.397. 
atasözü olmuş bilgece sözler (özdeyişler)i $i^{72}$ onların diğer bilgece fermanlari $^{73}$ gibi hukukî bir hüküm ifade ederdi. Buna bilge ataların sözlerini de dâhil etmek gerekir. Çünkü “Bu kültürlerde yasalar bile kalıplaşmış deyişlere, atasözlerine yerleşmiştir; bunlar yalnız yasa dilinin süsü değil, yasanın özüdür. Zaten sözlü kültürlerde çoğu kez yargıcın görevi, huzuruna getirilen resmî anlaşmazlığı adil karara bağlamak için dava konusuyla ilgili atasözlerini beyan etmektir."74 Nitekim Allah Elçisi Muhammet'in aşağıdaki sözleri de bu hususu teyit etmektedir:

'Mesut oğlu Abdullah'tan rivayet edildiğine göre Allah Elçisi Muhammet şöyle demiştir:

'İki haslet sahibinden başkasına gıpta edilemez. Bunlar da Allah tarafından kendisine mal ihsan olunup da doğru yolda harcayan kimse ile kendisine 'bilgece sözler/ özdeyişler/ vecizeler (el-hikme)' ihsan olunup onunla 'hükmeden' ve onu öğreten kimsedir.' ${ }^{\text {75 }}$

Allah da bir 'bilge (el-hakîm) kral'dır. Kuran'daki 'el-hikme' kelimesi onun bilgece sözleri/ özdeyişleri/ vecizeleri ${ }^{76}$ anlamında kullanılmıştır. ${ }^{77}$ Bunlar tıpkı bir babanın -ki krallar da tebaalarının babas1 ${ }^{78}$ olarak görülmüştür- oğluna nasihatleri gibidir. ${ }^{79} \mathrm{Bu}$ yüzden Kuran'da zikredilen Lokman'ın oğluna olan nasihatleri ile bir kral tanrı olarak Allah'ın kullarına olan nasihatleri hemen hemen aynıdir..$^{80}$

\footnotetext{
${ }^{72}$ Kanuni'nin darbımesel (atasözü) olmuş 'Halk içinde muteber bir nesne yok devlet gibi/ Olmaya devlet cihanda bir nefes sıhhat gibi' Mısıraları buna örnek verilebilir.

${ }^{73}$ es-Seâlibî, kitabında "Hükümdarların Bilgece Fermanları" adıyla bir 'fasıl' açarak örnekler verir. Bk. es-Seâlibî, age, s.73.

${ }^{74}$ Ong, age, s.51.

75 el-Buhârî, el-'ílm/ 15.

${ }^{76}$ Kelimenin bu anlamları için bk. Bilal Tan, Kur'an'da Hikmet Kavramı, İstanbul, Pinar Yay., (2000), s.23, 24, 92.

${ }^{77}$ Kuran'daki 'el-hikme' kavramı hakkında bk. Hacımüftüoğlu, age, s.165, 166.

${ }^{78}$ Kınalızâde tebaa ve hükümdar ilişkisini baba-oğul ilişkisi gibi görür. Bk. Unan, age, s.20, 21.

${ }^{79}$ Krş. “Bilgelik yapıtları, 'Bir köylünün Oğluna Öğ̈̈tleri”. Samuel Noah Kramer, Sümer Mitolojisi (çev.: Hamide Koyukan), İstanbul, Kabalcı Yay., (1999), s.42.

${ }^{80}$ Bk. el-En 'âm, 6/151-153; Lokman, 31/12-19; el-İsrâ', 17/22-39).
} 
Mükemmel, kusursuz ve bilge sayılan beşer bir kralın koyacağ 1 törelerin ve kanunların da -en azından teorik olarak- mükemmel ve kusursuz olması beklenir. Özellikle eski toplumlarda krallar ve diğer tür hükümdarlar sadece emredici ve yönetici değil, aynı zamanda 'töre koyucu' veya günümüzdeki modern kullanıma uygun olarak söyleyeceksek 'kanun koyucu'81 yöneticilerdi. Burada ara bir açıklama yapmakta fayda vardır. Yazılı kanunların pek bulunmadığı eski toplumlarda, hatta günümüzdeki modern İngiliz Krallı̆̆g'nda bile töreler aynı zamanda kanunların yerini tutmaktadır. ${ }^{82}$ Orhun Kitabeleri'nden anlaşıldığına göre eski Türk devletlerinde, hâkimiyetini Tanrı'dan alan hakan bu hâkimiyetini ve bağımsızlığını töre koyma şeklinde anlamaktaydı. Zaten devlet de töre koyan hakan ile ayakta kalabilmekteydi. ${ }^{83}$ "Osmanlı sultanlarının hükümdarlık yetkilerini kullanarak 'kânun koymağa' girişmeleri ve mesela Fatih'in meşhur teşkilat kanununun başında yer alan 'Bu kânunnâme atam ve dedem kânunudur, benim dahi kânunumdur. Evlâdı kirâmın neslen ba'de neslin bununla âmil olalar.' ifadeleri, öteden beri uygulanan geleneklerin ve tecrübe birikiminin, eski Türklerde olduğu gibi, Osmanlı devlet idaresinde de bir veri olarak nasıl kullanılmaya devam edildiğini ortaya koymaktadır. Eskinin 'töre'si, bu defa 'örf' veya 'yasağ-1 pâdişâhî' (padişah yasağı, kânunu) ismiyle yeni hayata, yeni şartlara intikal ve intibak etmiş demektir." 84

Allah da esasen 'töre koyucu' bir kral tanrıdır. Kuran'da 'töre'yi ifade etmek için kullanılan kelime ise 'ed-dîn'dir. ${ }^{85}$ Allah Elçisi Muhammet'in yaşadığı çağda bu kelime/ kavram günümüze

\footnotetext{
${ }^{81} \mathrm{Krş.} \mathrm{Kral} \mathrm{Hammurabi} \mathrm{hem} \mathrm{baş} \mathrm{yargıç} \mathrm{ve} \mathrm{hem} \mathrm{de} \mathrm{yasa} \mathrm{koyucuydu.} \mathrm{Ünlü} \mathrm{dikme}$ taşı üzerindeki temsilî resmi onu yasa koyucu olarak göstermektedir. Bk. Klengel, age, s.175.

82 Bk. "Töre" mad., (Komisyon), Sosyal Bilimler Ansiklopedisi, c.IV, s.145.

${ }^{83}$ Bk. Halil İnalcık, Osmanlı'da Devlet, Hukuk, Adâlet, İstanbul, Eren Yay., (2000), s.29.

${ }^{84}$ Unan, age, s.24.

85 'ed-Dîn' kelimesi 'töre/ adet' anlamının dişında 'devlet reisine veya krala itaat' anlamında da kullanılmıştır. Mevdudi şöyle der: "Bu hadisten [Yemrukûne mine'd-dîni murûka's-sehmi mine'r-râmiyyyeh: 'Okun yaydan çıkması gibi 'dîn'den çıkıyorlar.' rivayetini kastediyor] 'dîn' kelimesi ile kastedilen mananın burada devlet reisine itaat olduğu anlaşılıyor. İbn Esir de en-Nihâye adlı kitabında, 'Din-
} 
nazaran farklı bir anlam ve değer taşıyordu. O çağda ister Allah kaynaklı olsun, ister olmasın hayatın merkezinde 'ed-dîn' bulunuyor, 'hukuk, ahlak, etik ${ }^{86}$, din, yasa/ kanun, gelenek, kültür, töre, kural/ norm, inanç, düzen/ nizam, değer yargısı, öğreti...' vb. kavram ve değerler bir bütün halinde bu kelime ile ifade edilebiliyordu. Dolayısıyla klasik Arapçadaki ve Kuran'daki 'ed-dîn' kavramı, günümüz Türkçesindeki 'din' kavramından ve tabi ki 'töre' kavramından bir hayli genişti. Artık Türkçedeki 'din' ve 'töre' kelimeleri onun sadece birer parçasını oluşturabilmektedir.

'Gökler-Yer Krallığı'nın sahibi, efendisi ve kralı olması hasebiyle Allah, pek haklı olarak evrende carî 'töre (ed-dîn)'nin de yegâne müessisi olmaktadır. ${ }^{87}$ Onun töresinin en belirgin özelliği 'teslimiyet (islâm)'tir. Gökler ve yer ister istemez onun töresine boyun eğmiştir. Tebaası olan insanların da onun töresine uyması kadar doğal bir şey olamaz. es-Seâlibî dilimize Hükümdarlık Sanatı adıyla çevrilen Âdâbu'l-Mulûk adlı kitabında şöyle der: "Yaygın sözlerden biri de şu: 'Halk, yöneticisinin dini üzeredir.' İnsanlar başlarındaki hükümdarın temel doktrini ve inancı neyse ona meylederler. Onun görüşlerini referans olarak görürler. Onu taklit etmeye özen gösterirler." 88 Ancak Allah'ın töresinden imtina ederek başka töreler (el-edyân) kabul edenler daima var olmuştur.

'Göklerde ve yeryüzünde bulunanlar ister istemez Allah'a teslim olduğu, kendileri de ona iade edilecekleri halde onlar yine de onun töresinden başka bir töre (dîn) mi arzuluyorlar ?' (Âlu 'İmrân, 3/83)

den maksat taattır. Yani Hâriciler imama (devlet reisine) farz olan itaatten kaç1yorlar ve ondan tamamen tecerrüd ediyorlar.' diye açıklamıştır [Mevdudi, age, s.111, dipnot:5. Ayrıca bk. Izutsu, age, s.211]." Öte yandan yazılışları aynı fakat harekeleri farklı olan Arapça 'ed-dîn (töre; itaat; bağllık)' ve 'ed-deyn (borç)' kelimeleri aynı kökten (dâl, yâa', nûn) gelir. Bu husus bile zımnen, Allah'a itaatin ve bağllığın kulun borcu olduğunu göstermektedir.

${ }^{86} \mathrm{Krş}$. Türkçeye 'etik' olarak geçen Yunanca 'êthos' sözcüğünün asıl anlamı 'töre'dir. Bk. Bedia Akarsu, Felsefe Terimleri Sözlüğü, İstanbul, İnkılâp Kitabevi Yay., (1998), s.74.

${ }^{87}$ Yusuf suresinde 'kralın töresi'nden 'dîni'l-melik (Yusuf, 12/76)' diye söz edilir. Anılan tamlama ile günümüzde algıladığımız anlamda 'kralın dini (inancı)'nın kastedilmediği, bulunduğu bağlamdan kolaylıkla anlaşılabilir.

${ }^{88}$ es-Seâlibî, age, s.52. 
Eski devirlerde krallar ve diğer tür hükümdarlar her iki anlamda yani hem 'hüküm süren' ve hem de 'yarg1ç' 89 anlamında birer 'hâkim (hükmeden)' ${ }^{90}$ idiler. ${ }^{91}$ Çünkü onlar yasama, yürütme ve yarg1 erklerini bir elde; kendi ellerinde toplamışlard1. ${ }^{92}$ Kuran'a baktığımızda her ikisi de Allah'ın birer habercisi ve aynı zamanda babaoğul birer kral olan Davut ile Süleyman'ın tebaalarının davalarına baktıklarını öğreniyoruz. ${ }^{93}$ Yine Kuran'a göre Allah da her iki anlamda bir 'hâkim'dir; bir kral olarak göklerde ve yerde hükmeden ve aynı zamanda 'yargılanma günü (yevmu'd-dîn)' veya daha çok kullanılan bir ifadeyle 'duruşma günü (yevmu'l-kıyâme)' insanları yargılayacak bir 'yargıç.' Allah, o gün bütün insanlığı bir araya getirecek $^{94}$, çok hızlı ve adil bir biçimde onları yargılayacaktır. Bu yargılamada 'Zerre kadar iyilik yapan da; zerre kadar kötülük yapan da karşılığını görecektir (Zilzâl, 99/18).' Zira denilmiştir ki, “Eğer bir ülkede kötüler iyilik görür, iyiler de kötülük görürse orada iyilik ümidi kalmaz; padişahın emirlerini kimse dikkate almaz ve yanında kimse kalmaz. Bu yüzden hükümdar iyileri ödüllendirmeli, kötüleri de cezalandırmalıdır." 95 Dolayısıyla o gün 'Hiç kimseye bir haksızlık yapılmayacaktır (el-Enbiyâ', 21/47).' Kuran'da bu vb. birçok ifadeye rastlamak olasıdır:

\footnotetext{
${ }^{89} \mathrm{Krş}$. Nizâmü'l-Mülk, geçerli bir neden olmadıkça muhakemeyi/ yargılamayı bizzat padişahın yapması gerektiğini söyler. Bk. Nizâmü'l-Mülk, Siyâset-Nâme (yayına haz. Mehmet Altay Köymen), Ankara, Türk Tarih Kurumu Yay., (1999), s.31.

90 'Hükümdar (hüküm sahibi)' sözcügü de aslında her iki anlama gelir. 'el-Esmâu'l-husnấ' içinde geçen 'ed-deyyân' sıfatı da 'hâkim; yargıç' demektir. Bk. erRâzî, age, s.497.

${ }^{91}$ Belki de bu yüzden İngilizcede 'court' kelimesi hem 'saray' ve 'hem' de 'mahkeme' anlamında kullanılmaktadır. Bk. Robert Avery vd., İngilizce-Türkçe Redhouse Sözlüğü, İstanbul, Redhouse Yay., (1995), s.218.

${ }^{92} \mathrm{Krş.} \mathrm{“Kral} \mathrm{[Hammurabi]} \mathrm{baş} \mathrm{yargıç} \mathrm{ve} \mathrm{aynı} \mathrm{zamanda} \mathrm{yasa} \mathrm{koyucuydu} \mathrm{ve} \mathrm{ünlü}$ dikme taşı üzerindeki temsilî resim de onu yasa koyucu olarak göstermektedir... Ancak iradi olarak adaletin başefendisi olmasının dışında kral, (özellikle de Hammurabi'ye ilişkin olarak metinlerde belgelendiği gibi) davalarda doğrudan yargıçlık yapmıştır." Klengel, age, s.175.

${ }_{93}$ Bk. el-Enbiyâ',21/78, 79). Allah Elçisi Muhammet, kral olmayı kabul etmediği için bir kral olarak değilse bile, bir devlet başkanı olarak davalara bakmıştır. Bk. el-Buhârî, Fi'l-Mezâlimi ve'l-Ğadab/ 16; Ebû Dâvûd, el-Akdiyeh/ 7.

${ }_{94}^{4}$ Bk. Âlu 'İmrân, 3/9).

${ }^{95}$ Abdulhakim Koçin, Zâîfî-Gülşen-i Mülûk, Ankara, Akçağ Yay., (2005), s.115.
} 
‘Ulusların efendisi, mutlak insaflı, şefkatli ve yargılanma gününün tek hâkimi (mâliki yevmi'd-dîn) olan Allah bütün övünceleri haizdir (el-Fâtiha, 1/.2-4)!'

'Efendisinin huzurunda hesaba duracağından korkan ve bu yüzden kendi tutkularına gem vuran kimseye gelince, has bahçe onun yegâne barınağı olacaktır (en-Nâzi'ât, 79/40, 41).'

‘Bundan sonra da niçin yargılanmayı (d-dîn) inkâr edesin ki? Değil mi ki Allah 'en büyük yargıç (ahkemi'lhâkimîn)' tır (et-Tîn, 95/8).' ${ }^{\prime 96}$

‘Uneyis oğlu Abdullah rivayet eder:

'Allah habercisinden şunu dinlemiştim: 'Allah kulları toplar ve onlara 'Kral benim (Ene'l-melik)! Yargıç benim (Ene'd-deyyân)!' diye seslenir. Yakında olan onu duyduğu gibi uzakta olan da duyar. ${ }^{\prime 97}$

es-Seâlibî, hükümdardan bahisle, "Elbette insanlardan gizlenmesi; yakın dostları, nedimleri ve vezirleri dışında kimseye çıkmaması onun hakkıdır!.." der. Çünkü "hükümdarın tebaa karşısına fazla çıkması, gözlerin ona karşı kayıtsız ve boş bakmasına yol açabilir. Elbette ki bundan sakınmalı, tüm hareketlerine, heybetini, şanını ve satvetini artıracak şekilde yön vermeli, buna özen göstermelidir." Kendisi daha sonra eski bir Samanî emiri (Emir Mansur) ile veziri arasında geçen bir konuşmayı nakleder. Emir bir defasında maiyetiyle beraber sarayından ayrılıp etrafı çarşılarla ve evlerle kaplı bir meydanda savlece (eskiden oynanan bir tür kriket

\footnotetext{
${ }^{96}$ Kuran'da Allah için kullanılan 'el-fettâh (Sebe', 34/26)' sözcügü de 'yargıç (elhâkim)' anlamına gelmektedir. Bk. Çelik, age, s.112; er-Râzî, age, s.153.

${ }^{97}$ el-Buhârî, et-Tevhîd/ 32. Bir kral olarak kullarına 'yargıç'lık yapan Allah aynı zamanda onlara aralarındaki anlaşmazlıklar/ ihtilaflar konusunda 'hakem'lik de yapar. Allah elçisine ve yoldaşlarına ihanet eden Kurayzaoğulları kendilerine nasıl muamele edilmesi gerektiği konusunda Muaz oğlu Sad'ın hakemliğine müracaat ettikleri vakit o, akıl baliğ erkeklerinin öldürülmesine ve çocuklarının esir edilmesine hükmetmişti. Allah elçisi, Muaz'ın bu hükmünün ne kadar adil olduğunu -ifadedeki 'kral'dan Allah'ı kast ederek- 'Sen onlar hakkında kralın verdiği hükmü verdin (Legad hakemte fihim bi hukmi'l-melik).' diyerek onaylamıştı (Bk. elBuhârî, el-Cihâdu ve's-Siyer/ 168). Allah duruşma günü de Yahudilerin, Hıristiyanların ve Müslümanların 'dîn' ve ' $̂ m a ̂ n '$ ' konusundaki ihtilaflarını giderecektir. Nitekim bununla ilgili olarak Kuran'da 'Allah anlaşmazlığa düştüğünüz konular hakkında duruşma günü karar verecektir (el-Hacc, 22/69).' denilmektedir. Ayrıca bk. Âlu 'İmrân, 3/55; el-Mâide, 5/48; el-En'âm, 6/164; en-Nahl, 16/92).
} 
oyunu) oyunu oynamaya başlayınca veziri telaşla onun bulunduğu meydana gelir. 'Hayrola! Bir şey mi var, ihtiyar?' diye soran emire yaşlı vezirin verdiği cevap ilginçtir: "Asayiş berkemal, işler yolunda... Lakin hükümdar halkın gözüne fazla gözüküyor. Heybet az zuhur iledir, millet ne kadar zor ulaşabilirse ona, o kadar saygı, o kadar hürmet duyulur zatına! Yüce Rabb' in yaratıklarının gözlerinden gizlenmesi kadar yüksek bir hikmet var mı? Eğer Allah (c.c.) gözlere aşikâr olsaydı O'na ibadet edilir miydi?"'98 Frazer'in aktardığına göre Darfur sultanı, önce ağzını ve burnunu sonra da alnını örten müslin bir kumaşla yüzünü kapatmaktadır. Bu yüzden ona bakanlar sadece gözlerini görebilirler. Wadai sultanını ise hep bir perde gerisinden konuştuğu için yakınları ve ayrıcalıklı birkaç kişi haricinde hiç kimse görememektedir. ${ }^{99}$ Kuran'daki yegâne ve gerçek kral olan Allah da görülmez. ${ }^{100}$ Ama bu görülememe durumu zaten onun öncelikle çok uzaklarda bulunmasıyla ilgili bir durumdur. Görülemez çünkü yeryüzünde değil, genellikle göklerin ötesindedir. Dolayısıyla ona gösterilen bağlılık ve sadakat giyaben $($ bi'l- $\breve{g} a y b)$ dir. ${ }^{101}$

Yukarıda 'Allah'ın Krallı̆̆ı' ile ilgili zikrettiğimiz birkaç kelime, kavram, ifade ve hususun haricinde Kuran'da ve sahih rivayetlerde bu makalenin sınırlılıkları dâhilinde şimdilik detaylarına giremeyeceğimiz Allah'ın evinden (beyt) $)^{102}$, başkentinden (ummu'lkurâ $)^{103}$, has bahçelerinden (cennât $)^{104}$, zindanından (siccîn) $)^{105}$; kulla-

\footnotetext{
${ }^{98}$ es-Seâlibî, age, s.108, 109.

${ }_{99}$ Bk. James G. Frazer, Altın Dal (çev.: Mehmet H. Doğan), İstanbul, Payel Yay., (1991), s.158. Eski Japon İmparatorları II. Dünya Savaşı yenilgisine kadar yaklaşık 2000 yıl boyunca tebaalarının karşısına hiç çıkmamışlardı. Hatta 1926 yılında tahta çıkan imparator Hirohito 1945 yılında Amerikalılara teslim oluncaya kadar kendi devlet radyosundan hiç konuşma yapmamıştı.

${ }^{100} \mathrm{Krş}$. Wells, adı geçen eserine Görünmez Kral adını vermiştir.

${ }^{101}$ Bk. Fâtır, 35/18; el-Mulk, 67/12). Mukâtilu'bnu Suleymân, Tefsîru Mukâtili'bni Suleymân (tahk.: 'Abdu'llâh Mahmûd Şehhâte), Beyrut, Muessesetu't-Târîhi'1'Arabî, (2002), c.3III, s.555; c.IV, s.391.

102 Kureyş, 106/3.

${ }^{103}$ eş-Şûrâ, $42 / 7$.

104 Âlu 'İmrân, 3/15.

105 el-Mutaffifûn, 83/8, 9.
} 
rından, kölelerinden, işçilerinden, memurlarından, hizmetçilerinden ('ibâd $)^{106}$, halayıklarından (imấ $)^{107}$, kâtiplerinden (sefereh) ${ }^{108}$, 'Yüksek Konsey (el-meleu'l-A'lâ)'inden'109, yakın maiyetinden (el-mukarrebûn $)^{110}$, elçilerinden (rusul) ${ }^{111}$, habercilerinden (enbiyấ $\hat{a}^{\prime 12}$, ulaklarından (melâikeh $)^{113}$, kolluk kuvvetlerinden (zebânî̀) $)^{114}$, askerlerinden/ ordularından (cunûdu rabbik) ${ }^{115}$, hafiyelerinden (hâfizîn $)^{116} \ldots$ de söz edildiğini kısaca belirtmiş olalım.

Şimdi konumuzun en kritik sorusuna gelmiş bulunuyoruz: Acaba Kuran'da ve sahih rivayetlerde 'Allah'ın Krallığı' gerçek anlamda mı mecaz anlamda mı kullanılmıştır? Bizce yukarıda bir kısmını zikrettiğimiz de dâhil olmak üzere bütün deliller 'Allah'ın Krallığı'nın gerçek anlamda kullanıldığını ve ilk muhatapların gerçek anlamda anladıklarını göstermeye fazlasıyla kâfidir. Bu şekilde bir cevaptan sonra onu bir mecaz olarak kabul edenlerin -ki her ne kadar entelektüel söylemleriyle boy gösterseler bile görebildiğimiz kadarıyla hiçbiri bu konuda ciddi bir bilimsel merak, tahkik ve tefekkür ile bu sonuca ulaşmamıştır; araştırmaları tasvir edici, objektif

106 el-Furkân, 25/63.

${ }^{107}$ Muslim, el-Elfâzu mine'l-Edebi ve Ğayrihâ/ 3. Başka bir rivayette İsa'nın annesi Meryem de 'halayık (emeh)' olarak söz edilir: "Ve enne 'Îsâ 'abdu'llâhi ve'bnu emetih (Muslim, el-Îmân/ 10).” 'İsa, Allah'ın kulu ve halayığının oğludur.' et-Telemsânî der ki: 'Allah 'İleti (el-Kur'ân)' içinde Meryem dışında hiçbir kadını kendi adıyla anmamıştır. Meryem'i ise yaklaşık otuz yerde anmıştır. Bunun hikmeti şudur: Krallar veya eşraftan kimseler hür eşlerini kendi adlarıyla anmazlar; bunun yerine onları aileye nispet ederek [ya da ailedeki konumlarına göre] künyelerlerdi. Halayıklara/ cariyeler (imâ')e gelince onlara künye takmazlar; onların adlarını açıkça söylemekten çekinmezlerdi. Bu yüzden 'İleti'de Meryem'in ve oğlu İsa'nın adları, Allah'ın halayıklarından (imâu'llâh) ve kölelerinden olduklarına işaret etmek amacıyla açıkça anılmıştır...' Mevlânâ Ahmed Şihâbu'd-Dîn elHafâcî, Nesîmu'r-Riyâd fî Şerhi Şifâi'l-Kâdî 'Iyâd, Beyrut, Dâru'l-Kitâbi'l-'Arabi, (t.siz), c.1, s.136.

108 'Abese 80/15.

109 Sâd, 38/69.

110 el-Vâkı'a, 56/11; el-Mutaffifûn, 83/28; en-Nisâ', 4/172.

111 el-A 'râf, 7/43.

112 en-Nisâ', 4/155.

113 et-Tahrim, 66/6.

114 el-'Alak, 96/18.

115 el-Müddessir, 74/31.

116el- İnfitâr, 82/10. 
ve bütünsel olmaktan çok yüzeyseldir ve sadece bir kısım kelam ve tefsir otoritelerinin izahlarına ve tevillerine olan itimattan ibarettir. Hâlbuki 'İtimat kontrole mani değildir- müşebbihe ve mücessime ithamlarını ve bu çıkarsamayı yapan felsefi 'akl (zihniyet)'ı bir tarafa bırakarak metnin ne dediğine veya 'metnin ve ilk muhatapların aklı'nın ${ }^{117}$ ne olduğuna odaklanmaya çalışalım. Allahın krallığının gerçek bir krallık olduğuna ilişkin sayısız denecek argüman sıralanabilir. Ancak her ne kadar 'Arif olana tek bir işaret yeter (el-'Ârifu tekfihi'l-işâreh).' ise de biz birkaç argüman daha zikretmiş̧ olalım.

Kuran'da ve sahih rivayetlerde Allah'in 'kral (el-melik)' ve 'efendi; sahip ( $r a b b)$ olduğundan birçok kez bahsedilir. Ancak sadece bununla kalınmaz, mecaz olduğuna mahal vermeyecek tarzda açıkça 'gerçek kral (el-meliku'l-hakk)' ve 'gerçek efendiniz (rabbukumu'l-hakk)' şeklinde de bahsedilir.

'Gerçek kral yücedir. Ondan başka hiçbir tanrı yoktur. Yüce tahtın sahibidir(el-Mu'minûn, 23/.116).'

'Gerçek kral yücedir. Sana işaret buyurma tamamlanmadan okumak için acele etme (Tâhâ, 20/114)'.'

'İşte size gerçek efendiniz olan Allah (Yunus, 10/35) !'

Ebuhureyre şöyle rivayet eder:

'Allah'ın adı dâhil 99 sıfatı vardır. Kendisi tektir ve teki sever. Kim bu ad ile sıfatları ezberlerse has bahçeye girer: Allah.... Gerçek kral (el-meliku'l-hakk)...'118

Dolayısıyla Allah'tan açıkça 'gerçek kral (el-meliku'l-hakk)' ve 'gerçek efendiniz (rabbukumu'l-hakk)' şeklinde bahsedildikten sonra onun mecaz (istiare) olarak ' $\mathrm{kral}^{\prime}$ olduğu nasıl iddia edilebilir ki? Aslında sadece bu üç ayet ve tek sahih rivayet bile iddiamızı ispata kâfidir ve tartışmayı bitirir. Öte yandan Allah'ın gerçekten bir kral olması bir yana sahih bir rivayete bakılırsa duruşma günü artık (yevmu'l-kıyâme) Allah'tan başka kral yoktur yani kalmayacaktır ve onun en çok öfke duyduğu kimse (dünyada) unvanı 'krallıkların kralı' olan kimsedir.

117 Öyle görünüyor ki, hâlihazırda kullandığımız 'akıl', Kuran ve sahih rivayet metinlerde bulunmayan ‘harici bir akıl' ve delildir. Çünkü metinler bu 'akl'ı veya emarelerini bizlere 'maalesef' vermemektedir.

118 İbnu Mâce, Esmâu'llâh/ 10. 
'Ebu Hureyre'nin rivayetine göre Allah elçisi şöyle demiştir:

'Yüce Allah'ın duruşma günü en fazla öfkeleneceği kimse unvanı 'krallıkların kralı (meliku'l-emlâk)' olan kimsedir. Zira Yüce Allah'tan başka kral yoktur (Lâ melike ille'llâh).'119

Eğer Allah gerçek bir kral değilse niçin en fazla unvanı 'krallıkların kralı' olan kimseye öfkelensin ki? Bu rivayet kanaatimize göre aynı zamanda şunu da ima etmektedir: 'Krallıkların kralı' veya 'krallar kralı (meliku'l-mulûk)' unvanını kullananlar hangi manada kullanıyorsa Allah da o anlamda kullanmaktadır. Allah bu unvanı kullananlara öfkelenmektedir çünkü gerçekte mezkûr unvan yalnızca kendisine aittir. Aşağıdaki benzer iki sahih rivayet de aslında Allah'ın gerçek bir kral (el-meliku'l-hakk) olduğunu ispatlar mahiyettedir:

‘Ebu Hureyre, Allah elçisinden şunları işittiğini rivayet eder:

'Yüce Allah yeri toplar ve sağ eliyle gökleri dürer. Sonra, 'Kral benim! Yeryüzünün kralları nerede?' diye sorar.'120

Bu rivayette Allah, 'Kral benim! Yeryüzünün kralları nerede? (Ene'l-melik. Eyne mulûku'l-ard)' sözleriyle diğer krallara meydan okumakta; kendisi varken başka kralların esamisinin okunmayacağını dile getirmekte ve bir bakıma kendisi ile yeryüzündeki kralları mukayese etmektedir. Bu da aynı şeyden (kral olmaktan) bahsettiğini gösterir. Çünkü aynı şeyler/ cinsler arasında kıyas yapmak

119 el-Buhârî, el-Edeb/ 114. Ayrıca bk. el-Beyhakî, age, c.I, s.65. el-Lu'lu've'lMercân'da el-Buhârî rivayeti “Bâbu Tahrîmi'l-Musemmâ bi Meliki'l-Emlâki ve bi Meliki'l-Mulûk (Krallıkların Kralı veya Kralların Kralı Şeklinde Unvan Koymanın Yasaklanışı ile İlgili Bölüm)" başlığı altında verilir (Bk. Muhammed Fuâd 'Abdu'l-Bâkî, el-Lu'lu' ve'l-Mercân, İstanbul, Dâru Temel li'n-Neşri ve't-Tevzî', (1985), c.II, s.178). Rivayette geçen 'meliku'l-emlâk' tamlaması şöyle açıklanmaktadır: “Meliku'l-emlâk ne demektir? 'Emlâk', 'milk'in cem'i olduğuna göre, memleketlerin kıt'aların sahibi ve hükümrânı demektir. Bu cihetle bu hadisin ravilerinden Süfyan İbn-i ‘Uyeyne 'meliku'l-emlâk'i birçok zevatın 'Şâhinşâh' diye terceme ettiklerini bildirmiştir ki, 'pâdişahların pâdişâhı' demektir [ez-Zebîdî, age, c.12. s.163]." Öte yandan Nizâmü'l-Mülk, Siyâset-Nâme adlı eserinde sultanı Melikşah'dan 'Şâhinşâh-1 A'zam [En Büyük Şahlar Şahı]' ve 'Hüdavend [Efendi; Sahip]' olarak söz eder. Bk. Nizâmü'l-Mülk, age, s.6, 7, 84.

120 el-Buhârî, et-Tefsîr-ez-Zumer/ 2; ed-Dârimî, er-Rikâk/ 80. 
daha makuldür. Dolayısıyla onlardan bahsederken kullandığg 'melik (çoğ. mulûk)' kelimesi hangi anlama geliyorsa kendisi için kullandığı 'melik' kelimesi de aynı anlama gelir. Eğer Allah kendisi için sadece 'mâlik' kelimesini kullansaydı -ki bazıları Allah için kullanılan 'mâlik' kelimesinden yola çıkarak 'melik'i 'malik' olarak izah etme çabasındadırlar- o takdirde onun bir ' $k$ ral' olmadığını iddia edebilirdik. Ancak kendisi için 'mâlik' kelimesini kullandığı gibi 'melik' kelimesini de kullanmaktadır. Bu da gösteriyor ki, 'mâlik'den kasit 'melik (kral)'tir. Zira özel olan geneli açıklar.121 Fikıh Usulünde cumhurun kabul ettiği bir kaide ile izah edeceksek, 'Lâ yuhmelu'lhâssu ale'l-âmm (Özel olan genel olana hamledilmez).' Yani başka bir ifade ile söyleyecek olursak 'Mutlak mukayyete hamledilir.'

'Beşir oğlu Numan, Allah elçisinden şunu işittiğini rivayet eder:

'Dikkatinizi çekerim! Her kralın bir koruluğu vardır. Dikkatinizi çekerim! Allah'ın koruluğu da yasak ettiği alanlardan ibarettir... (Elâ ve inne li kulli melikin himâ. Elâ ve inne hime'llâhi mehârimuh... $)^{\prime 122}$

Allah elçisinin 'Her kralın bir koruluğu vardır. Allah'ın koruluğu da yasak ettiği alanlardan ibarettir.' sözünde bahsettiği 'melik (kral)' hangi anlama geliyorsa, Allah için bahsettiği 'melik' de aynı anlama gelmektedir. Nasıl ki ‘Her sultanın bir sarayı vardır. Mehmet'in sarayı ise Topkapı sarayıdır.' cümlesinden Mantıktaki tümdengelim (dedüksiyon) metoduyla açıkça söylenmese bile Mehmet'in gerçekten bir 'kral' olduğunu çıkarsayabiliyorsak 'Her kralın bir koruluğu vardır. Allah'ın koruluğu da yasak ettiği alanlardan ibarettir.' cümlesinden de Allah'ın gerçek bir kral olduğunu rahatlıkla çıkarsayabiliriz. Kaldı ki Kuran'da ve sahih rivayetlerde zaten Allah 'gerçek kral (el-meliku'l-hakk)' olarak nitelendirilmektedir.

Son olarak tahtı, orduları, askerleri, memurları, işçileri, memurları, kulları, köleleri, halayıkları vs. olmayan birisi için 'Falan kişi bu yerin kralıdır.' gibi bir ifade kullanıldığında bu ifadenin o

121 'Mâlik' kelimesi, 'melik' kelimesinden daha geniş anlamlıdır.' el-Askerî, age, s.133; Muhammedu'bnu 'Alî eş-Şevkânî, Fethu'l-Kadîr, Beyrut, Dâru'l-Kelimi'tTayyib, (1998), c.I, s.26.

${ }^{122}$ Muslim, el-Musâkât/ 20. Ayrıca bk. el-Buhârî, el-Îmân/ 39. 
kimsenin gücünü, kudretini, nüfuzunu, otoritesini veya zenginliğini anlatmak için yapılmış bir istiare olduğu yani mecazen kullanıldığı hemen anlaşılır. Dolayısıyla o kimsenin gerçek bir kral olduğu kimsenin aklına gelmez. Ancak bir kimsenin, daha önce yukarıdakilerden çok fazlasına temas ettiğimiz bir kralın sahip olması gereken değişik vasıfları, hasletleri, krallık müesseseleri vs. varsa o kimse (Allah) gerçek kraldır.

Peki, Kuran'da zikredilen Allah'ın 'taht ('arş)'ı gerçek anlamda mı, mecaz anlamda mı kullanılmıştır? Normal olarak her kralın bir tahtı olur. Her ne kadar bizde taht'ın mecaz (istiare) olduğu iddia ediliyorsa da kelimenin geçtiği bütün ayetler ve sahih rivayetler onu mecaz bir 'taht' olarak değil, bildiğimiz ve aşına olduğumuz somut bir 'taht' olarak tanıtmaktadır. Nitekim taht hakkında özellikle rivayetlerde oldukça çok ayrıntı verilmiştir. Tahtın ne kadar muazzam $(e l-' a z i ̂ m)^{123}$ olduğu, müştemilatından sayılan ve gökler ile yeri kaplayacak (vesi'a kursiyyuhu's-semâvâti ve'l-ard) ${ }^{124}$ derecede büyük olan ayak taburesi (kursî) ile kıyas edilerek ${ }^{125}$ anlatılır. Bundan başka tahtın nerede bulunduğundan ${ }^{126}$, Allah'ın üstüne ('ale'l-'arş/ fevka'l-'arş) bir yazı astığından ${ }^{127}$, elçisi Muhammet'in duruşma günü altına (tahte'l-'arş) kadar gideceğinden ${ }^{128}$, habercisi İbrahim'in karşısında/

\footnotetext{
${ }^{123}$ et-Tevbe, 9/129).

124 el-Bakara, 2/255).

${ }^{125}$ Bk. İbnu Kesîr, Tefsîru'l-Kur'âni'l-'Azîm (tahk.: Muhammed İbrâhîm el-Bennâ vd.), İstanbul, Kahraman Yay., (1992), c.I, s.458.

126 Ebû Dâvûd, es-Sunneh/ 19.

127 el-Buhârî, et-Tevhîd/ 15; Muslim, et-Tevbeh/ 4.

128 et-Tirmizî, Sıfatu'l-Kıyâmeti ve'r-Rekâikı ve'l-Vera'/ 10. Ayrıca bk. el-Buhârî, et-Tevhîd/ 36; Muslim, el-Îmân/ 84. 'Ebuzer der ki: 'Allah elçisine, Allah'ın 'Güneş de duracağı yere doğru akıp gitmektedir (Yâsîn, 36/38).' sözünün anlamı hakkında soru sordum. Bana 'Güneşin duracağı yer tahtın altıdır.' dedi.' elBuhârî, et-Tefsîr-Yâsîn/ 1.
} 
önünde oturacağından (mustakbile'l- 'arş) ${ }^{129}$, elçisi Musa'nın bir ayağına (kâimeti'l-'arş) veya ucuna (cânibi'l-'arş) tutunacağından ${ }^{130}$, tahtının ağırlığından (zinete 'arşih)131, ağırlığından dolayı ses çıkardığından ${ }^{132}$, gölgesinden (zıllı'l-'arş) ${ }^{133}$, gölgesinde asılı duran altından kandiller (kanâdîle min zehebin mu'allakatin fì zlllı'l-'arş) bulunduğundan ${ }^{134}$, iç kısımlarından (butnâni'l-'arş) ${ }^{135}$, etrafından (min havli'l-'arş/ 'alâ ercâihâa) $)^{136}$, sağından (yemîni'l-'arş) ${ }^{137}$, Bayındır Ev (elBeytu'l-Ma'mûr)'in hizasında (hizâe'l-'arş) bulunduğundan ${ }^{138}$, Muaz oğlu Sad'ın ölümü sebebiyle sarsıldığından/ yerinden oynadığından (ihtezze'l-'arş) ${ }^{139} \ldots$ söz edilir. Bu taht, duruşma günü sekiz hizmetkâr erkin (melek) omuzlarında ${ }^{140}$ bir tahtırevan gibi 'taşınarak

${ }^{129}$ Ebû Ca'fer Muhammedu'bnu Cerîr et-Taberî, Tefsîru't-Taberi [Câmi'u'l-Beyâni fî Te'vîli'l-Kur'ân], Beyrut, Dâru'l-Kutubi'l-'İlmiyyeh, (2005), c.VIII, s.133.

130 el-Buhârî, fi'l-Husûmât/ 1. Ayrica bk. el-Buhârî, er-Rikâk/ 43, et-Tevhîd/ 31; Muslim, el-Fedâil/ 42; Ebû Dâvûd, es-Sunneh/ 14; et-Tirmizî, Tefsîru'l-Kur'ân-ezZumer/ 40.

${ }^{131}$ Muslim, ez-Zikru ve'd-Du'âu ve't-Tevbetu ve'l-İstiğfâr/ 19; İbnu Mâce, elEdeb/ 56.

132 Ebû Dâvûd, es-Sunneh/ 19.

133 ed-Dârimî, el-Buyû'/ 50.

${ }^{134}$ Ebû Dâvûd, el-Cihâd/ 27. Ayrica bk. et-Tirmizî, et-Tefsîr-Âlu 'İmrân/ 4; İbnu Mâce, el-Cihâd/ 16.

135 İsmâ'îlu'bnu Muhammed el-'Aclûni, Keşfu'l-Hafâi ve Muzîlu'l-İlbâs (tashîh: Muhammed 'Abdu'l-'Azîzi'l-Hâlidi), Beyrut, Dâru'l-Kutubi'l-'İlmiyye, (2002), no:263, c.I, s.85.

136 ez-Zumer, 39/75; el-Mu'min, 40/7; el-Hâkka, 69/17.

137 et-Tirmizî, el-Menâkıb/ 1.

138 et-Taberi, age, c.XI, s.481.

139 el-Buhârî, Menâkıbu'l-Ensâr/ 12. Ayrıca bk. Muslim, Fedâilu's-Sahâbe/ 24; etTirmizî, el-Menâkıb/ 51; en-Nesâî, el-Cenâiz/ 113; İbnu Mâce, el-Mukaddime/ 11. ${ }^{140}$ Burada niçin 'sekiz' hizmetçinin taşıdığı merak edilebilir. Çünkü tahtırevanlar iki, dört veya sekiz hizmetkârın omuzlarında taşınır. İbn Batuta, Hindistan'daki anılarını anlattığı seyahatnamesinde yanına getirilen bir tahtırevanı şöyle tarif eder: "Bu araç hükümdar tahtına benzemektedir, üstüne ipek yahut pamuktan örülmüş bir örtü serilir... Sekiz kişi grup halinde ikiye ayrılarak dörder dörder nöbetleşe bu perdeli tahtırevanı taşırlar." Ebû Muhammed İbn Batûta, İbn Batûta Seyahatnamesi (çev.: Sait Aykut), İstanbul, Yapı Kredi Yay., (2004), c.II, s.731. 
$(\text { yahmilu })^{\prime 141}$ mahkeme alanına getirilecektir. ${ }^{142}$ Hatta diyebiliriz ki Kuran'da ve sahih rivayetlerde geçen 'taht ('arş)' sözcügü hiçbir zaman mecaz anlamda kullanılmamıştır. Çünkü bir kelime (isim) mecaz olarak kullanıldığında onun sıfatları ve özellikleri hakkında teferruata girilmez -mesela 'konuya el atmak' deyimindeki 'el'in büyüklüğünden, ağırlığından, uzunluğundan, parmaklarından, ayasından vs. söz edilemez ve buna dair soru sorulamaz- ve ayrıca istiarede bir şey eğreti alınır; her şey alınmaz. Öte yandan Allah için kullanılan " arş' kelimesini 'hâkimiyet' vb. mecaz anlamlarda anlamak isteyenler 'Ve yahmilu 'arşe rabbike fevkahum yevmeizin semâniyeh (el-Hâkka, 69/17).' yani 'O gün sekiz erk (melek) efendinin tahtını üzerlerinde taşır.' ifadesini mecaz olarak izah edemezler. Çünkü sekiz erkin üzerlerinde taşıdığı şeyin ağırlığı olan somut bir varlık (nesne) olması gerekir. Zaten öyle olmasaydı yukarıda bilvesile zikrettiğimiz Mutim oğlu Cubeyir rivayetinde 'Allah elçisi, -Parmaklarını kubbe gibi yaparak ve 'Isşte böyle!' diye göstererek- 'Allah, tahtının üzerinde, tahtı ise göklerin üzerindedir...' ${ }^{143}$ şeklinde bir ifade kullanmazdi.

\footnotetext{
${ }^{141}$ el-Hâkka, 69/17.

${ }_{142}$ Bazı eski kültürlerde hükümdarlar, hizmetçi uşakların omuzlarında taşıdıkları üstü örtülü ve tekerleksiz bir taşıt olan 'tahtırevan'a binerek gitmek istedikleri yere giderlerdi. Frazer, eski Japon imparatoru Mikado'nun, ayağının yere değmesinin saygınlığına ve kutsallığına çok aykırı bir şey olduğunu düşündüğü için, bir yere gitmek istediği zaman, insanların omuzları üzerinde taşındığını aktarır. Bk. Frazer, age, s.112.

${ }^{143}$ Ebû Dâvûd, es-Sunneh/ 19. Halife oğlu Abdullah'dan nakledilen benzer bir rivayet şöyledir: 'Kadının biri Allah habercisine gelmişti. Ona, 'Allah'a seslen (dua et) de beni has bahçeye koysun.' dedi. Bunun üzerine Allah habercisi, şanı yüce efendisini yüceltip şöyle dedi: 'Allah'ın ayak taburesi gökleri ve yeri kuşatmıştır. Kendisi üzerine oturur. Ayak taburesinin sadece dört parmak kadar kısmı ondan fazla gelmektedir -Bunu parmakların bir araya getirerek dedi-. Ayrıca ayak taburesinin, yeni yapılmış bir semerin üzerine binen kimsenin ağırlı̆ı̆ndan dolayı çıkan gıcırtı gibi bir gıcırtısı vardır [et-Taberi, age, c.III, s.12. Ayrıca bk. Celâlu'd-dîn es-Suyûtî, ed-Durru'l-Mensûr fi't-Tefsîri'l-Me'sûr (tahk.: 'Abdu'llâhi'bnu 'Abdi'l-Muhsini't-Turkî), Kahire, Merkezu Hacere li'l-Buhûsi ve'd-Dirâsâti'l-'Arabiyyeti ve'l-İslâmiyye, (2003), c.VI, s.164].' Allah elçisinin efendisine seselenirken kullandığı 'tahtının ağırlığınca (zinete 'arşih)' ifadesi için bk. Muslim, ez-Zikru ve'd-Du'âu ve't-Tevbetu ve'1-İstiğfâr/ 19; İbnu Mâceh, elEdeb/ 56.
} 
Bütün bu anlatılanlara paralel olarak Kuran'da Allah için kullanılan 'mulk' ve 'melekût' kelimelerinden kasıt da 'krallık'tır. ${ }^{144}$ 'Mulk' kelimesi ile 'melekût' kelimesinin farkı, aynı kök ve anlama sahip olmalarına rağmen ikincisinin birincisine nazaran mübalağalı bir kalıp olmasıdır ${ }^{145}$ ki bize göre yukarıdaki detaylara ek olarak bu durum bile gerçek anlamda kullanıldığına bir karinedir. Sonuç olarak 'melik'i 'kral' yerine 'hükümran', 'mulk/ melek $\hat{u} t^{\prime} \mathrm{u}$ 'krallık' yerine 'hükümranlık' şeklinde tercüme etmek ya da hiç tercüme etmemek yani 'melik' ve 'mülk/ melekût' diye geçiştirmek bilimsel olarak değerlendirilecek bir tutum değildir.

\section{Sonuç}

Bu makalemizde özellikle 610-632 yılları arasında yani Allah Elçisi Muhammet'in 'habercilik (nubuvvet)' ve 'elçilik (risâlet)' görevlerini ifa ettiği zaman dilimi içinde Kuran'da ve sahih rivayetlerde yoğun bir şekilde ortaya konulan, Allah'ın daha iyi tanınması ve Kuran'ın anlaşılması için vazgeçilmez olduğunu düşündüğümüz 'Allah'ın Krallığı' algısını bilimsel yöntemlerle bir bütün halinde ana hatlarıyla tasvir etmeye ve ortaya koymaya çalıştık. Şüphesiz ulaştığımız sonuçlar, kullandığımız dil ve yaptığımız çeviriler ilk bakışta garip ve alışılmadık gelebilir. ${ }^{146}$ Hatta konu ile alakalı yaptığımız bütün izahlara rağmen bazı hususların kapalı kaldığı da düşünülebilir. Bunu büyük ölçüde, daha önce konu ile ilgili müstakil bir çalışmanın yapılmamasına, tasvir etmeye çalıştı̆̆ımız algının pek bilinmemesine, meseleye yaklaşımımızın ve metodumuzun farklı olmasına bağliyoruz. ${ }^{147}$

${ }^{144}$ Daha önce geçen Allah'ın 'Büyüklük ve azamet benim üstlük ve altlık iki elbisemdir. Bu konularda benimle rekabete kalkışanı ateşe atarım [Ebû Dâvûd, elLibâs/ 28; Muslim, el-Birru ve's-S1latu ve'l-Âdâb/ 38] rivayetinin orijinal Arapça metninde geçen ve 'azamet' olarak çevirdiğimiz 'el-kibriyâ" sözcüğü dolaylı olarak 'krallık' olarak anlaşılmaktadır. Bk. Yunus, 10/78); et-Taberi, age, c.VI, s.579; er-Râzî, age, s.239.

${ }^{145}$ Bk. Nâsıru'd-dîn Ebû Sa'îd 'Abdu'llâhi'bnu 'Umar el-Beydâvî,, Tefsîru'l-Beydâvî [Envâru't-Tenzîl ve Esrâru't-Te'vîl] tahk.: Muhammed Muhyi'd-dîn el-Asfar, Beyrut, Dâru'l-Ma'rifeh, (2013), s.327.

${ }^{146}$ Çeviri olgusuna bakışımız için bk. Hacımüftüoğlu, Kuran Tercümelerinde Yöntem sorunu, s.29-80; 168-321.

${ }^{147}$ Çalışmamızın daha iyi anlaşılması için, araştırma safhasında bizim yaptığımız gibi daha önce bir şekilde edindiğimiz ya da bize dikte edilen Allah algısını ve 
Bu çalışmayı yapmamızın temel amacı Allah Elçisi Muhammet devrindeki 'Allah'ın Krallı̆̆ı' algısını bilimsel yöntemlerle bir bütün halinde tasvir etmek ve ortaya koymak olduğundan, önce Kuran' da ve sahih rivayetlerde sonra da günümüze kadar yazılmış yerli ve yabancı kitaplarda, makalelerde bulunan konuyla ilgili bilgileri taradık. Ayrıca başta Kitab-ı Mukaddes olmak üzere 'Tanrı'nın Krallığı' ile ilgili bazı Yahudi ve Hıristiyan kaynaklarını gözden geçirdik. Son olarak geçmişteki ilkel toplumlardan günümüzdeki modern toplumlara kadar değişik milletlerde ve kültürlerde oluşan 'tanrı kral' ve 'beşer kral'larla ilgili algılamaları araştırarak 'Allah'ın Krallığı' ile bunlar arasındaki paralellikleri ve bağlantıları tespit etmeye çalıştık.

Makalemizde uyguladığımız araştırma metodunun, geçmiş herhangi bir medeniyeti mesela Sümer veya Asur medeniyetini araştıran bir arkeologun veya tarihçinin kullandığı bilimsel metottan pek bir farkı bulunmamaktadır. Çünkü bize göre, 610-632 tarihleri arasında Arabistan yarımadasında oluşan 'Allah' veya 'Allah'ın Krallığ' ${ }^{\prime}$ algisını araştırmada ve tespit etmede kullanılacak metodun, binlerce yıl önce Mezopotamya'da oluşan herhangi bir 'tanrı' algısını araştırmada ve tespit etmede kullanılan bilimsel metottan bir farkı olmamalıdır. Bu tür araştırmalarda her şey olduğu gibi görülmeli ve gösterilmelidir. Elde edilen bulgular kendi bütünlügü̈ içinde izah edilmeye çalışılabilir. Ancak bunu araştırmacı asla zorlama yorumlara tevessül etmeden, olabildiğince inancını, kabullerini ve zihniyetini işin içine karıştırmadan yapmalıdır. Kaldı ki bize göre objektif hareket eden bir bilim adamı tespit ettiği bir algının/ olgunun muhtemel neticelerinin hesabını vermek; onu yerleşik inançlarla irtibatlandırarak savunmak ya da reddetmek zorunda değildir. Bu nedenle, araştırma sürecinde yerleşik inançlar ve kabuller -buna bilimsel olduğu farz edilen bazı kabuller de dâhildirile olan bütün irtibatlar olabildiğince kesilmeli daha doğrusu bunlar zihnin bir köşesinde yedekte tutulmalıdır. Eğer yerleşik inançlarla ve kabullerle olan irtibatlar kesilmezse ‘Dinim ve imanım elden gidiyor? Ben ne yapıyorum?' gibi bazı vehim ve endişeler araştırmacıyı yanlış yönlendirebilir; farkında olmadan onu şartlandırabilir.

buna sebep olan zihniyeti geçici olarak da olsa bir kenara koyarak tamamen farklı bir zihniyetle ve olabildiğince objektif olarak konulara bakmamız gerekmektedir. 
Durum böyle olunca da araştırmacı ne kadar çabalarsa çabalasın yerinde saymaktan ve miras aldığ fikirleri tekrar etmekten öteye gidemez. Dolayısıyla bize göre bilimsel bir araştırma, birtakım vehimlerle, endişelerle ya da bazı şeyleri ispat etme adına yapılmaz. Çünkü gerçek bilim adamı bir siyasetçi, fanatik bir dindar veya bir avukat gibi hareket edemez. Onun birinci görevi olması ya da ispatlanması gerekeni değil, kendisinin ya da başkasının hoşuna gitmese bile gayet soğukkanlı bir şekilde 'olan'ı veya 'algılanan'ı olduğu gibi görmek ve ortaya koymak, başka bir deyişle 'objektifi/ objektivitesi' ile 'olan'ın veya 'algılanan'ın fotoğrafını çekmektir.

Makalemizde 'Allah'ın Krallığı' konusunu dil ve tarih ağırlıklı olarak ele almaya çabaladık. Bu sebeple araştırma boyunca incelenen dilsel ve tarihsel kaynaklara yazım sürecinde yeri geldikçe atıflar yaptık ve yine yeri geldikçe onlardan bazı alıntılarda da bulunmuş olduk. Makale formatının getirdiği sınırlılıklarından dolayı daha geniş olarak ele alınması ve tartışılması gereken -kelime anlamıyla- antropomorfik (insanbiçimsel) ifadelere pek girmedik; dilsel ve tarihsel olarak ilk muhatapların zihninde gerçek bir 'krallık'ın var olup olmadığına odaklanmaya çalıştık.

Sonuç olarak 'Allah'ın Krallığı'nın ayetlerin ve sahih rivayetlerin sarih, doğrudan veya dolaylı delaletleriyle ilk muhatapların zihninde gerçek bir krallık olarak algılandığını gerek Kuran'da gerek sahih rivayetlerde bahsedilen Allah'ın, bir krala benzetilmesi veya 'kral'llğın onun için istiare edilmesi bir yana, her şeyiyle; adı, namları, sanları (unvanları), sıfatları, hasletleri, değişik özellikleri, krallığı (mulk; melekût), evi (beyt), başkenti (ummu'l-kurâ), has bahçeleri (cennât), zindanı (siccîn); kulları, köleleri, işçileri, memurları, hizmetçileri ('ibâd), halayıkları (imâ'), kâtipleri (sefereh), 'Yüksek Konsey (el-meleu'l-A'lâ)'i, yakın maiyeti (el-mukarrebûn), elçileri (rusul), habercileri (enbiyâ'), ulakları (melâikeh), kolluk kuvvetleri (zebânî), askerleri/ orduları (cunûdu rabbik), hafiyeleri (hâfızîn) ... ile baştan ayağa bir kral olarak algılandığını tespit ettik. Evet, günümüzdeki mevcut algımıza ve zihniyetimize ters gelebilir ama onlar gökte gerçek bir efendileri ve kralları bulunduğuna, onun kulu, kölesi ve hizmetkârı olduklarına inanıyorlardı. Doğrusu Kuran ve sahih rivayetler bizim tecsim ve teşbih diye nitelediğimiz ve kullanmaktan şiddetle kaçındığımız sayısız ifadenin hiç sakınma ve sınırlama gereği duyulmadan gerek Allah, gerek elçisi ve gerek ilk inananlar 
tarafından rahatlıkla kullanıldığını göstermektedir. Bu bağlamda 'sahih inancı korumak adına' başkaları hakkında tecsim ile teşbih iddiasında ve ithamında bulunanların bu iddialara kalkışmadan önce Allah elçisi ve sahabe devrinde bu iddiaların, ithamların ve bunları doğuran zihniyetin/ aklın var olup olmadığını veya hangi karşılaşmalar ve etkileşimler sonucu ortaya çıktığını, çıkış tarihini ve sürecini de dikkate alarak tamamen kişisel bir merakla ve bilimsel kaygılarla araştıracak bir cesarete sahip olmalarını ve bu gerçekle yüzleşmeye kalkışmalarını salık veriyoruz.

\section{Kaynakça}

Abdulhakim Koçin, Zâ̂̂fî-Gülşen-i Mülûk, Ankara, Akçağ Yay., (2005)

Abdu'r-Rahmân Berkûkî, Şerhu Dîvâni Hassâne'bni Sâbitini'l-Ensârî, Mısır, el-Mektebetu't-Ticâriyyetu'l-Kubrâ, (1929)

Ahmet Çelik, Kur'an Semantiği Üzerine, Erzurum, Kültür Eğitim Vakfı Yay., (2002)

André Clot, Muhteşem Süleyman (çev.: Turhan Ilgaz), İstanbul, Milliyet Yay., (1998)

Arthur Jeffery, The Foreign Vocabulary of The Qur'ân, Baroda, Oriental Instute, (1938)

Bedia Akarsu, Felsefe Terimleri Sözlüğ̈̈, İstanbul, İnkılâp Kitabevi Yay., (1998)

Bediuzzaman Said Nursi, Muhakemat, İstanbul, Envar Neşriyat, (1995)

Bediuzzaman Said Nursi, Sözler, İstanbul, Envar Neşriyat, (1995)

Bilal Tan, Kur'an'da Hikmet Kavramı, İstanbul, Pınar Yay., (2000)

Celâlu'd-dîn Abdurrahmân es-Suyûtî, el-Câmi'u's-Sağî̀, Beyrut, Dâru'l-Kütübi'l-'İlmiyye, (2004)

Celâlu'd-dîn Abdurrahmân es-Suyûtî, ed-Durru'l-Mensûr fi't-Tefsîri'lMe'sûr (tahk.: 'Abdu'llâhi'bnu 'Abdi'l-Muhsini't-Turkî), Kahire, Merkezu Hacere li'l-Buhûsi ve'd-Dirâsâti'l-'Arabiyyeti ve'l-İslâmiyye, (2003)

Cengiz Batuk, Tarihin Sonunu Beklemek, İstanbul, İz Yay., (2003)

Ebû 'Abdi'llâh el-Huseyn ez-Zevzenî, Şerhu'l-Mu'allakati's-Seb', Beyrut, Dâru'l-Ma'rifeh, (2004)

Ebû 'Abdi'llâh el-Huseyn ez-Zevzenî], Yedi Askı (çev.: Kenan Demirayak; Nevzat H. Yanı;; Nurettin Ceviz), Ankara, Ankara Okulu Yay., (2004)

Ebû Bekr Ahmedu'bnu'l-Huseyni'bni 'Alî el-Beyhakî, el-Esmâ' ve's-Sifât (tahk.: eş-Şeyh 'İmâdu'd-dîn Ahmed Haydar), Beyrut, Dâru'lKitâbi'l-'Arabî, (2002) 
Ebû Ca'fer Muhammedu'bnu Cerîr et-Taberî, Tefsîru't-Taberi [Câmi'u'lBeyâni fî Te'vîli'l-Kur'ân], Beyrut, Dâru'l-Kutubi'l-'İlmiyyeh, (2005)

Ebü'l-Kasım Cârullâh Muhammed b. Ömer ez-Zemahşerî,, el-Keşşâf, Beyrut, Dâru'l-Kütübi'l-'İlmiyye, (2009)

Ebû Muhammed İbn Batûta, İbn Batûta Seyahatnamesi (çev.: Sait Aykut), İstanbul, Yapı Kredi Yay., (2004)

Ebû Mansur es-Seâlibî, Hükümdarlık Sanatı (çev.: Sait Aykut), İstanbul, İnsan Yay., (1997)

Edip Yüksel, Mesaj Kuran Çevirisi, İstanbul, Ozan Yay., (2003)

Fahri Unan, İdeal Cemiyet İdeal Devlet İdeal Hükümdar, Ankara, Lotus Yay., (2004)

Günay Tümer; Abdurrahman Küçük, Dinler Tarihi, Ankara, Ocak Yay., (1993)

Halil Hacımüftüoğlu, Kuran Tercümelerinde Yöntem Sorunu, İstanbul, İz Yay., (2008)

Halil Hacımüftüoğlu, "Kuran'da ve Hadislerde 'Rabb' Sıfatının ve 'Rukû"' ile 'Secde' Fiillerinin Tahsisi", Bilimname, (2013)

Halil İnalcık, Osmanlı'da Devlet, Hukuk, Adâlet, İstanbul, Eren Yay., (2000)

Hilmi Yavuz vd., Dinler Tarihi Ansiklopedisi, İstanbul, Gelişim Yay., (t.siz)

H. G. Wells, Görünmez Kral Tanrı (çev.: Hatice Çoban), İstanbul, İzdüşüm Yay., (2000)

Homeros, İlyada (çev.: Azra Erhat; A. Kadir), İstanbul, Can Yay., (1993)

Horst Klengel, Kral Hammurabi ve Babil Günlü̆ğ̈ (çev.: Nesrin Oral), İstanbul, Telos Yay., (2001)

Hüseyin Atay; İbrahim Atay, Arapça-Türkçe Büyük Lügat (Mu'cemu'l-Luğa), Ankara, (1964)

Hüseyin Atay, Kur'an Türkçe Çeviri, Ankara, Atay ve Atay, (2002)

el-Isbehânî, Ebu'l-Ferec, Kitâbu'l-Ĕğânî (tahk.: eş-Şeyh Ahmed eş-Şankîtî), Matba'atu't-Tekaddum, Misır, (t.siz)

İbnu Kesîr, Tefsîru'l-Kur'âni'l-'Azîm (tahk.: Muhammed İbrâhîm el-Bennâ vd.), İstanbul, Kahraman Yay., (1992)

İbrahim Canan, Kütüb-i Sitte Muhtasarı Tercüme ve Şerhi, Ankara, Akçağ Yay., (1990)

İsmâ'îlu'bnu Hammâd el-Cevherî,, Mu'cemu's-Sihâh (i'tinâ': Halîl Me'mûn Şeyhâ), Beyrut, Dâru'l-Ma'rifeh, (2008)

İsmâ'îlu'bnu Muhammed el-'Aclûni, Keşfu'l-Hafâi ve Muzîlu'l-İlbâs (tashîh: Muhammed 'Abdu'l-'Azîzi'l-Hâlidi), Beyrut, Dâru'l-Kutubi'l-'Ilmiyye, (2002),

İsmail Parlatır vd., Türkçe Sözlük, Ankara, Türk Dil Kurumu Yay., (1998) 
Jacques Ellul, Sözün Düşüşü (çev.: Hüsamettin Arslan), İstanbul, Paradigma Yay., (2004)

James G. Frazer, Altın Dal (çev.: Mehmet H. Doğan), İstanbul, Payel Yay., (1991)

Jean Bottéro, Mezopotamya (çev.: Ayten Er; Mehmet Emin Özcan), Ankara, Dost Kitabevi Yay., (2003)

J. Walter Ong, Sözlü ve Yazılı Kültür (çev.: Sema Postacıoğlu Banon), İstanbul, Metis Yay., (2003)

Luis Şeyhû, Enîsu'l-Culesâ' fi Şerhi Dîvâni'l-Hansâ', Beyrut, (1896)

Mevdudi, Kur'an'a Göre Dört Terim (çev.: İsmail Kaya; Osman Cilacı), İstanbul, Beyan Yay., (t.siz)

Mevlânâ Ahmed Şihâbu'd-Dîn el-Hafâcî, Nesîmu'r-Riyâd fî Şerhi Şifâi'l-Kâdî 'Iyâd, Beyrut, Dâru'l-Kitâbi'l-'Arabi, (t.siz)

Muhammed Arkoun, Kur'an Okumaları (çev.: A. Zeki Ünal), İstanbul, İnsan Yay., (1995)

Muhammed Esed, Kur'an Mesajı Meal-Tefsir (çev.: Ahmet Ertürk; Cahit Koytak), İstanbul, İşaret Yay., (1996)

Muhammed Fuâd 'Abdu'l-Bâkî, el-Lu'lu' ve'l-Mercân, İstanbul, Dâru Temel li'n-Neşri ve't-Tevzî̀', (1985)

Muhammed Hamidullah, "İslam'da Sembolik Anlatım ( çev.: Sadık Kılıç)”, Ankara, Diyanet Dergisi, (1989)

Mukâtilu'bnu Suleymân, Tefsîru Mukâtili'bni Suleymân (tahk.: 'Abdu'llâh Mahmûd Şehhâte), Beyrut, Muessesetu't-Târîhi'l-'Arabî, (2002)

Nâsıru'd-dîn Ebû Sa'îd 'Abdu'llâhi'bnu 'Umar el-Beydâvî,, Tefsîru'l-Beydâvô [Envâru't-Tenzîl ve Esrâru't-Te'vîll] tahk.: Muhammed Muhyi'd-dîn elAsfar, Beyrut, Dâru'l-Ma'rifeh, (2013)

Nevzat Tarhan, Akıldan Kalbe Yolculuk: Bediüzzaman Modeli, İstanbul, Nesil Yay., (2012)

Nizâmü'l-Mülk, Siyâset-Nâme (yayına haz. Mehmet Altay Köymen), Ankara, Türk Tarih Kurumu Yay., (1999)

Ömer Faruk Yavuz, Kur'an'da Sembolik Dil, Ankara, Ankara Okulu Yay., (2006)

Ramazan Yazçiçek, “Metafizik Alanda Sörf ya da Mecaz ve Semboller Üzerinden Anlamlandırma: Bir Anlatım Yöntemi Olarak Metafor", Milel ve Nihal, (2012)

Robert Avery vd., Ingilizce-Türkçe Redhouse Sözlüğ̈̈, İstanbul, Redhouse Yay., (1995)

Sadi, Gülistan (çev.: Hikmet İlaydın), Ankara, Milli Eğitim Bakanlığı Yay., (1946)

Salih Akdemir, Son Çağrı Kur'an, Ankara, Ankara Okulu Yay., (2004) 
Samuel Noah Kramer, Sümerler (çev.: Özcan Buze), İstanbul, Kabalcı Yay., (2002)

Samuel Noah Kramer, Sümer Mitolojisi (çev.: Hamide Koyukan), İstanbul, Kabalcı Yay., (1999)

Serdar Mutçalı, Arapça-Türkçe Sözlük, İstanbul, Dağarcık Yay., (1995)

Sibel Özbudun, Ayinden Törene, İstanbul, Anahtar Kitaplar Yay., (1997)

Suad Yıldırım, Kur'ân-ı Hakîm'in Açıklamalı Meali, İstanbul, Işık Yay., (2005)

S.R.F. Price, Ritüel ve İktidar (çev.: Taylan Esin), Ankara, İmge Kitabevi Yay., (2004)

Süleyman Ateş, Kur'an'ı-Kerim ve Yüce Meali, İstanbul, Yeni Ufuklar Neşriyat, (t.siz)

Şaban Piriş, Kur'an-ı Kerim Türkçe Anlamı, İstanbul, Okyanus Yay., (2004)

Talat Koçyiğit, Kur'an-ı Kerim Meali, Konya, Nükte Yay., (2005)

Thomas Hobbes, Leviathan (çev.: Semih Lim), İstanbul, Yapı Kredi Yay., (2008)

Toshihiko Izutsu, Kur'ân'da Allah ve İnsan (çev.: Süleyman Ateş), Ankara, Kevser Yay., (t.siz)

(Komisyon), Sosyal Bilimler Ansiklopedisi, İstanbul, Risale Yay., (1990)

(Komisyon), el-İncîl li'l-kıddîsi Yuhannâ, Kahire, Dâru'l-Ma'ârif, (1997)

(Komisyon), İncil-Müjde, İstanbul, Yeni Yaşam Yay., (1991)

(Komisyon), Kutsal Kitap-Yeni Çeviri-, İstanbul, Kitab-1 Mukaddes Şirketi Yay., (2003)

(Komisyon), Kânûn-i Esâsî, Meclîs-i Meb'ûsân Riyâset Başkitâbetî, İstanbul, (h. 1330)

Nicolo Machiavelli, Hükümdar (çev.: Selahattin Bağdatlı), İstanbul, Der Yay., (1999)

Ömer Özsoy, "Dinsel Bir Metin Olarak Kur'an'ın Bazı İfade Özellikleri”, I. Kur'an Sempozyumu, Ankara, Bilgi Vakfı Yay., (1994)

er-Râğı el-Isfehânî, Mufredâtu Elfâzi'l-Kur'ân (nşr. Safvân Adnân Dâvûdî), Dimeşk, Dâru'l-Kalem, (1992)

Will Durant, Kıssatu'l-Hadârah [The Story of Civilation] (çev.??), www.alsakher.com (28.06.2010)

Yusuf Besalel, Yahudilik Ansiklopedisi, İstanbul, Gözlem Gazetecilik Basın ve Yayın A.Ş. Yay., (2002)

Zeki Özcan, Teolojik Hermenötik, İstanbul, Alfa Basım Yayım Dağıtım, (1998)

Zeynü'd-dîn Ahmed b. Ahmed b. Abdi'l-Latîf ez-Zebîdî, Sahîh-i Buhârî Muhtasarı Tecrîd-i Sarîh Tercemesi ve Şerhi (terc. ve şerh: Ahmed Naim; Kâmil Miras), Ankara, Diyanet İşleri Başkanlığı Yay., (1982)

Zeynü'd-Dîn Ebû 'Abdi'llâh er-Râzî,, Tefsîru Ğarîbi'l-Kur'âni'l-'Azîm (tahk.: Hüseyin Elmalı), Ankara, Türkiye Diyanet Vakfı Yay., (1997) 